\title{
Spring-summer temperatures reconstructed for northern Switzerland and southwestern Germany from winter rye harvest dates, 1454-1970
}

\author{
O. Wetter ${ }^{1,2}$ and C. Pfister ${ }^{1,2}$ \\ ${ }^{1}$ Oeschger Centre for Climate Change Research, University of Bern, Bern, Switzerland \\ ${ }^{2}$ Institute of History, Section of Economic-, Social- and Environmental History (WSU), University of Bern, Bern, Switzerland
}

Received: 28 April 2011 - Published in Clim. Past Discuss.: 4 August 2011

Revised: 7 October 2011 - Accepted: 21 October 2011 - Published: 29 November 2011

\begin{abstract}
This paper presents a unique 517-yr long documentary data-based reconstruction of spring-summer (MAMJJ) temperatures for northern Switzerland and southwestern Germany from 1454 to 1970 . It is composed of 25 partial series of winter grain (secale cereale) harvest starting dates (WGHD) that are partly based on harvest related bookkeeping of institutions (hospitals, municipalities), partly on (early) phenological observations. The resulting main Basel WGHD series was homogenised with regard to dating style, data type and altitude. The calibration and verification approach was applied using the homogenous HISTALP temperature series from $1774-1824$ for calibration $(r=0.78)$ and from 1920-1970 for verification $(r=0.75)$. The latter result even suffers from the weak data base available for 18701950. Temperature reconstructions based on WGHD are more influenced by spring temperatures than those based on grape harvest dates (GHD), because rye in contrast to vines already begins to grow as soon as sunlight brings the plant to above freezing. The earliest and latest harvest dates were checked for consistency with narrative documentary weather reports. Comparisons with other European documentarybased GHD and WGHD temperature reconstructions generally reveal significant correlations decreasing with the distance from Switzerland. The new Basel WGHD series shows better skills in representing highly climate change sensitive variations of Swiss Alpine glaciers than available GHD series.
\end{abstract}

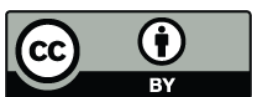

Correspondence to: $\mathrm{O}$. Wetter (oliver.wetter@hist.unibe.ch)

\section{Introduction}

Cereals are the most widely grown crops in Europe since the Neolithic Revolution. Bread was the basic food in most European societies, and before the advent of the railway, grain prices were known to be the key indicator of economic activity (Persson, 1999), comparable to oil-prices today (Pfister, 2010). Not surprisingly, European archives contain a huge amount of documentation related to grain cultivation that was, unlike grape harvest dates, hardly yet investigated for climate reconstruction. This paper presents a 517-yr long reconstruction of spring-summer (MAMJJ) temperatures from documentary-based winter rye (secale cereale) harvest starting dates covering the period from 1454 to 1970 . Documentary sources contain two different kinds of evidence, namely: (a) narrative accounts on (unusual) weather spells and weather-induced disasters; and (b) (bio) physical proxy indicators such as advances or delays of vegetation in the summer half year (AMJJAS) and the presence or absence of frost, ice and snow-cover in the winter half year $(O N D$ JFM) (Pfister, 1992; Brázdil et al., 2005; Leijonhuvhud et al., 2010). From the twelfth century onwards, chroniclers occasionally referred to (bio) physical evidence as a means to provide data on pronounced temperature anomalies that could be compared over time (Wegmann, 2005; Pfister et al., 2009). However, such narratives are singular and relatively short, ending at the latest with the death of the observer (Pfister et al., 2009). Long-term biophysical evidence was generated by institutions such as chapters and municipalities in the context of bookkeeping. If entries allow the precise dating of weather-dependant agricultural or commercial activities,

Published by Copernicus Publications on behalf of the European Geosciences Union. 


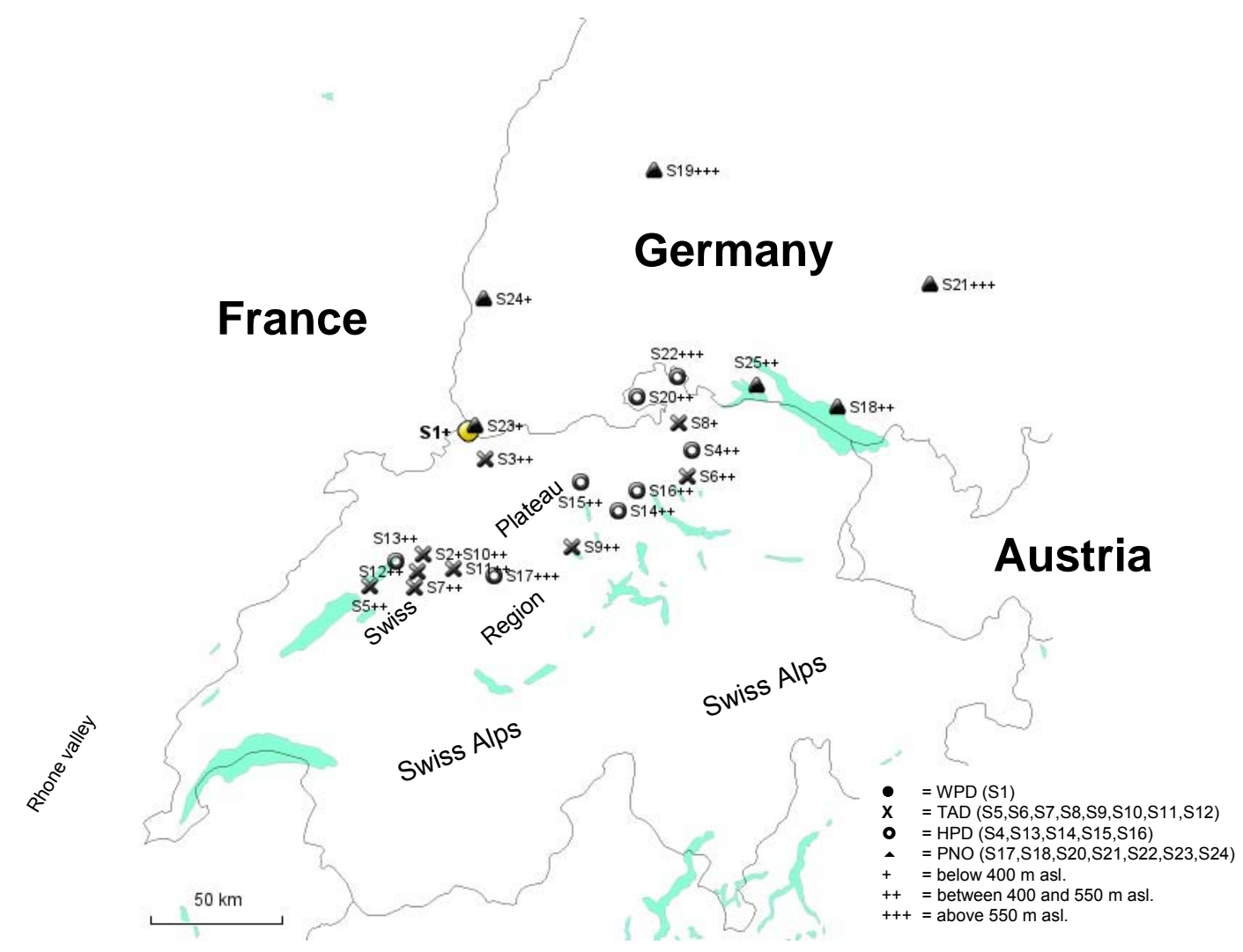

Fig. 1. Location of WPD, TAD, HPD and PNO series in northern Switzerland and south-western Germany.

such information can be used as a climate proxy. In general, accounting procedures remained stable over long periods and therefore such institutional sources have the potential to yield century-long series of annual, quantitative and relatively homogeneous proxy data. Grape harvest starting dates (GHD) are the best known example of this kind of data (e.g. Le Roy Ladurie, 1967; Le Roy Ladurie and Baulant, 1980; Burkhardt and Hense, 1985; Lauer and Frankenberg, 1986; Pfister, 1988; Souriau and Yiou, 2001; Chuine et al., 2004; Menzel, 2005; Meier et al., 2007; Rutishauser et al., 2007; Bràzdil et al., 2008; Mariani et al., 2009; Maurer et al., 2009). More recently, Leijonhufvud et al. (2008, 2010) showed that the start of the sailing season each year, as deduced from post- 1500 custom ledgers and other documents related to harbour activities in Stockholm, can be used as a reliable proxy for January to April (JFMA) temperatures, at least until the beginning of the 1870s. Kiss et al. (2011) provided a May to July temperature reconstruction of $\mathrm{Bu}-$ dapest based on five vine- and grain-related historical phenological series from the town of Kôszeg (West-Hungary). As there was a sufficient overlap between the proxy series and the (early) instrumental period, the approach of calibration and verification (Cook et al., 1994) could be used for these reconstructions.
This paper draws on a similar evidence for the start of the cereal harvest from 1454 to 1970 in north-west Switzerland and south-west Germany. The geographical setting of the 25 locations is shown in Fig. 1. Switzerland is located in central Europe and divided up into three major geographic regions, namely the Alps, the Jura Mountains and their foothills and the intermediate region called the Swiss Plateau, where most of its 7.8 million inhabitants live (BFS, 2010). The investigation area is situated in a zone of transitional climate influenced by both maritime and continental air masses. Predominant winds come from the west. Other typical winds are the "bise", a cold wind from northeast being channelled by the Plateau narrowing in southwest, and the northern alpine "foehn" (downslope wind from the south), causing remarkable temperature risings. At same altitude, the temperature decreases from west to east due to a more continental-influenced climate. Annual average rainfall varies between $800 \mathrm{~mm}$ (in the lee of the Jura Mountains) and more than $2500 \mathrm{~mm}$ in the High Alps, with a summer maximum. The climate in the Jura Mountains, located north of the Alps in France, Switzerland and Germany, is colder than that of the Swiss Plateau (Schüepp et al., 1978; Encyclopaedia Britannica, 2011). Disregarding the Swiss Plateau (1), the region of interest concerns the northern foothills of the Jura mountains (2), the Upper Rhine Valley (3), and the Swabian 


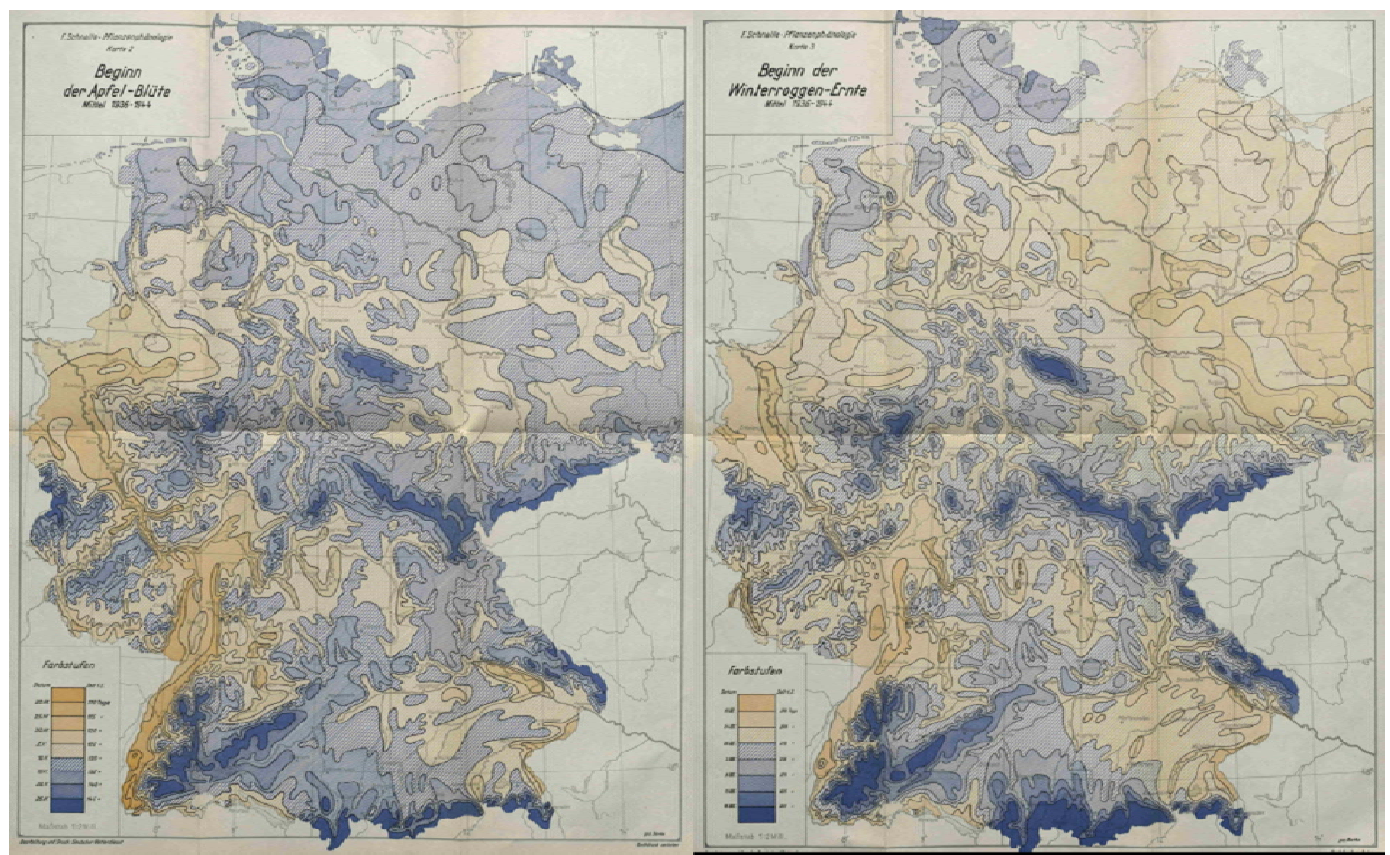

Fig. 2. Start of flowering of apple trees (left panel); begin of winter rye harvest (right panel) between 1936 and 1944 in Germany (1:2 000 000 ) by Schnelle (1955).

Alps (4) in south-western Germany (Fig. 1). The Basel area - situated at the upper end of the Upper Rhine Plain - enjoys an exceptionally mild climate, influenced at times by Mediterranean air currents flowing up the Rhone valley. The Upper Rhine Plain, framed by the French Vosges Mountain range in the west and the German Black Forest Mountain range in the east, could heat up enormously in the summer half year. Annual precipitation shows windward and leeward patterns, caused by both mountain ranges. Temperatures and sunshine duration in the Basel area are clearly above those of the Swiss Plateau region (Schüepp et al., 1978). The regional climatic differences are well reflected by plant phenology, as the example from Germany demonstrates (Fig. 2).

The value of WGHD as a proxy indicator for March to July temperatures was discovered by Pfister (1979, 1992). WGHD were mainly investigated in the northern countries where GHD are not available (Tarand and Kuiv, 1994; Tarand and Nordli, 2001; Nordli et al., 2003). Nordli (2001) used proxy data from five farmers' diaries in central Norway (from 1805) to assess temperatures in Trondheim before the beginning of systematic instrumental measurements in 1858 . The same author provided a summary of the relevant work on farmer's diaries in Norway (Nordli, 2007). Likewise, WGHDs were used in the Czech Republic as a substitute for GHDs (Brázdil and Kotyza, 2000; Mozny et al., 2011). Recently, Pribyl et al. (2011) submitted a paper reconstructing April-July mean temperatures from 1256 to 1431 in Norfolk (England) based on grain harvest starting dates from administrative records.
This paper is structured as follows: The first section presents the evidence and addresses its reliability from a historical and scientific point of view. The steps to merge partial series of different proxies into main WGHD series considering proxy-type, dating style and altitude are outlined in the second section. The third section concerns the statistical reconstruction of spring-summer (MAMJJ) temperatures using the calibration and verification approach. In the fourth section, the results of the reconstruction are presented, discussed and compared with other documentary based temperature reconstructions as well as glacier fluctuations in the central Alps. Conclusions are drawn in the fifth section.

\section{The evidence}

The onset of grain harvesting not only depends on the occurrence of the degree of full ripeness, which is difficult to determine, but also on human decision-making. The onset of rainy spells may postpone the start of the harvest. On the other hand, if the grain became overripe, there was the risk of substantial dropouts of grains through the harvesting work (Allen and Lueck, 2002), which clearly limited possible postponement of harvest. For these reasons, the onset of grain harvest is subsumed by phenologists under the "aprocryphal" (i.e. questionable) phases (DWD, 1991). This premise matters for discussing the evidence used to create the 517-yr long series of WGHDs. Four kinds of evidence are distinguished: 


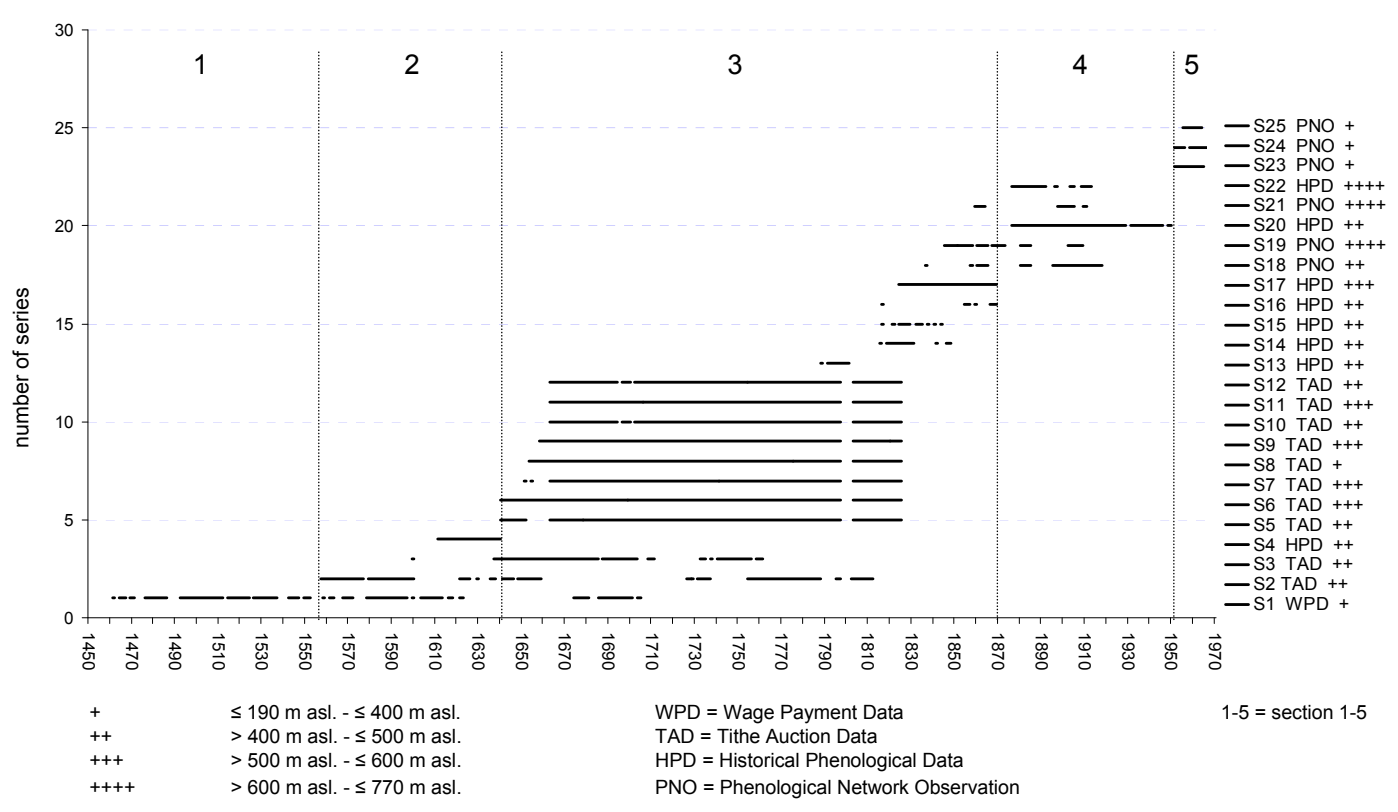

Fig. 3. Composition of Basel WGHD series; consisting of WPD, TAD, HPD and PNO series from northern Switzerland and south-western Germany.

- Wage payment dates (WPD) (Figs. 3 and S1 in the Supplement

Exploring the account books of the Czech town of Louny Brázdil and Kotyza (2000), we discovered that the date of wage payments to day labourers paid on Saturdays could be used as a proxy indicator for temperature. The document lists the weekly wages paid on Saturdays, specifying the type of work performed, such as hay and grain harvest, work in the vineyards, cutting of ice on the river, carrying out water from flooded cellars, etc. The discovery of the two authors matters for historical climatology. Account books are among the most frequently available continuous archival documents and hence it suggested itself to look for similar data elsewhere. The authors of the present article looking through the books of daily expenditures kept by the hospital in Basel (Switzerland) were tapping into a climate-historical gold-mine. This source contains a wealth of evidence about the beginning of a multitude of different kinds of agricultural field and vineyard work from 1454 to 1705 for the same location (Figs. 3; S1 in the Supplement, Table 1; source 1).

In the early fourteenth century, the Basel hospital, founded somewhat before 1265, was a municipal institution managed by a fraternity. Wardens and nurses elected by the municipality replaced the friars around 1400. Although the hospital was not funded by the town, both the clerics as well as the secular administration were accountable to the town council. A hospital was a profit-orientated enterprise in those days rather than a philanthropic institution. For the well-off, the hospital acted as old-age pension and disability insurance in cases of corresponding donations. The hospital cared for disabled Basel citizens. Sick persons needed to transfer their entire belongings to the hospital. If they recovered, they got them back. If they died, they became property of the hospital (von Tscharner-Aue, 1983).

Under these conditions, the hospital acquired manifold possessions such as tenements, commercial buildings, estates, tithes and "bonds". The town council granted the hospital exemption from tithe and consumption taxes in 1339. In 1436, the hospital already drew earnings from estates in 85 villages situated in today's Greater Basel Region, including neighbouring France, Germany and Switzerland. An appropriate bookkeeping was established in the mid-fifteenth century. More than 240 books of expenditures from 1454 to 1705 have survived. Potential climate-historical evidence only comes from estates that were directly farmed by the hospital on the basis of hired labour. Unlike the weekly payments customary in the Town of Louny (Brázdil and Kotyza, 2000), labourers in Basel were paid at the end of every single working day. The first appropriate entry thus represents the actual beginning of the corresponding agricultural activity (Fig. 4).

The books of daily expenditures did not survive after 1705 , though they were most probably continued. In any case, they were not any more archived, contrary to the annual accounting books. At least we are left 
Table 1. Archival- and edited archival sources.

\begin{tabular}{|c|c|c|c|}
\hline Sources & Originator & Title & Archive \\
\hline source 1 & $\begin{array}{l}\text { Hospital } \\
\text { of Basel }\end{array}$ & Ausgabenbücher 1454-1705 & $\begin{array}{l}\text { Spitalarchiv F12 } \\
\text { Staatsarchiv } \\
\text { Basel-Stadt }\end{array}$ \\
\hline source 2 & $\begin{array}{l}\text { Gerung, } \\
\text { Niklaus }\end{array}$ & $\begin{array}{l}\text { Des Kaplans Niklaus Gerung genannt Blauenstein Fortsetzung der Flores Temporum } \\
\text { 1417-1475, in: Basler Chroniken, Band 7, Historische Antiquarische Gesellschaft Basel } \\
\text { (ed.), Hirzel, Leipzig, 1915. }\end{array}$ & \\
\hline source 3 & $\begin{array}{l}\text { Bullinger, } \\
\text { Heinrich }\end{array}$ & Chronik 1532-1566 & $\begin{array}{l}\text { Burgerbibliothek } \\
\text { Bern }\end{array}$ \\
\hline source 4 & $\begin{array}{l}\text { Haller, } \\
\text { Wolfgang }\end{array}$ & Kalender mit handschriftlichen Einträgen, 1545-1576 & $\begin{array}{l}\text { Zentralbibliothek } \\
\text { Zürich }\end{array}$ \\
\hline source 5 & $\begin{array}{l}\text { Sprüngli, } \\
\text { J. Jakob }\end{array}$ & Witterungstagebücher & $\begin{array}{l}\text { Burgerbibliothek } \\
\text { Bern }\end{array}$ \\
\hline source 6 & $\begin{array}{l}\text { Künzli, } \\
\text { Anton }\end{array}$ & Chronik & $\begin{array}{l}\text { Stadtbibliothek } \\
\text { Winterthur }\end{array}$ \\
\hline source 7 & $\begin{array}{l}\text { Steffen, } \\
\text { Ulrich }\end{array}$ & Rechenbuch, angefangen den 24. Jan. Ao. 1791 & $\begin{array}{l}\text { Stadtbibliothek } \\
\text { Winterthur }\end{array}$ \\
\hline source 8 & $\begin{array}{l}\text { Aubrion, } \\
\text { Jean }\end{array}$ & $\begin{array}{l}\text { Journal Avec une continuation du de Pierre Aubrion. 1465-1512. Lorédan Larchey } \\
\text { (ed.), Metz } 1857 .\end{array}$ & \\
\hline source 9 & $\begin{array}{l}\text { Tschudi, J., } \\
\text { Heinrich }\end{array}$ & $\begin{array}{l}\text { Beschreibung des Lobl. Orths und Lands Glarus, Joh. Heinr. Lindinners (ed.), } \\
\text { Zürich, } 1714 .\end{array}$ & \\
\hline source 10 & $\begin{array}{l}\text { Vigneulles, } \\
\text { Philippe }\end{array}$ & $\begin{array}{l}\text { Chronique de Philippe de Vigneulles editée par Charles Bruneau, Tome } 3 \text { (de l'an } 1473 \\
\text { à l'an 1499), Metz, } 1932 .\end{array}$ & \\
\hline source 11 & $\begin{array}{l}\text { Edlibach, } \\
\text { Gerold }\end{array}$ & $\begin{array}{l}\text { Gerold Edlibach's Chronik, nebst einem Anhange mit Sorgfalt nach dem Original copirt } \\
\text { und mit einer gleichzeitig verfertigten Anschrift genau verglichen und aus derselben } \\
\text { vermehrt und ergänzt von Joh. Martin Usterj. Meyer und Zeller, Zürich, } 279 \text { pp., } 1846 .\end{array}$ & \\
\hline source 12 & $\begin{array}{l}\text { Cysat, } \\
\text { Renward }\end{array}$ & $\begin{array}{l}\text { Stationes anorum. Witterung, Missjahre, Teuerung, in: Collectanea pro Chronica } \\
\text { Lucernensi et Helveticae, 1. Bd., 2./3. Teil, Diebold Schilling, Luzern, 898-963, } 1969 .\end{array}$ & \\
\hline source 13 & $\begin{array}{l}\text { Bächtold, } \\
\text { Jakob }\end{array}$ & $\begin{array}{l}\text { Hans Salat, ein schweizerischer Chronist und Dichter aus der ersten Hälfte des XVI. } \\
\text { Jahrhunderts. Sein Leben und seine Schriften, Bahnmeier, Basel, } 1876 .\end{array}$ & \\
\hline source 14 & $\begin{array}{l}\text { Kappeler, } \\
\text { J. Heinrich }\end{array}$ & $\begin{array}{l}\text { Chronik von Frauenfeld aus den Jahren 1600-1663, in: Thurgauische Beiträge zur } \\
\text { vaterländischen Geschichte, Schaltegger, F. (ed.), 55, } 1913 .\end{array}$ & \\
\hline source 15 & $\begin{array}{l}\text { Brunschwiler, } \\
\text { Placidus }\end{array}$ & Diarium Fischingense 1616-1654. & $\begin{array}{l}\text { Stiftsarchiv } \\
\text { Einsiedeln }\end{array}$ \\
\hline source 16 & $\begin{array}{l}\text { Bourban, } \\
\text { Pière }\end{array}$ & Chronique de Caspard Bérody, Fribourg, 1894. & \\
\hline source 17 & $\begin{array}{l}\text { Monastery of } \\
\text { Beinwil- } \\
\text { Mariastein }\end{array}$ & Zehntenbuch von Beinwil-Mariastein 1588-1672. & $\begin{array}{l}\text { Klosterarchiv } \\
\text { Mariastein } \\
\text { (sign. BMA 92) }\end{array}$ \\
\hline source 18 & $\begin{array}{l}\text { Monastery of } \\
\text { Beinwil- } \\
\text { Mariastein }\end{array}$ & Zehntenbuch von Beinwil-Mariastein 1673-1711. & $\begin{array}{l}\text { Klosterarchiv } \\
\text { Mariastein } \\
\text { (sign. BMA 92) }\end{array}$ \\
\hline source 19 & $\begin{array}{l}\text { Monastery of } \\
\text { Beinwil- } \\
\text { Mariastein }\end{array}$ & Verzeichnis der Zehnten des Gotteshauses Beinwil 1712-1761. & $\begin{array}{l}\text { Klosterarchiv } \\
\text { Mariastein } \\
\text { (sign. BMA 96) }\end{array}$ \\
\hline source 20 & $\begin{array}{l}\text { Monastery of } \\
\text { Beinwil- } \\
\text { Mariastein }\end{array}$ & Zins- und Zehntenrechnungen von Beinwil-Mariastein 1595-1705. & $\begin{array}{l}\text { Klosterarchiv } \\
\text { Mariastein } \\
\text { (sign. BMA 351) }\end{array}$ \\
\hline
\end{tabular}


Table 1. Continued.

\begin{tabular}{|c|c|c|c|}
\hline Sources & Originator & Title & Archive \\
\hline source 21 & $\begin{array}{l}\text { Monastery of } \\
\text { Beinwil- } \\
\text { Mariastein }\end{array}$ & Zehnten- und Bodenzinsrodel von Mariastein 1682-1688. & $\begin{array}{l}\text { Klosterarchiv } \\
\text { Mariastein } \\
\text { (sign. BMA 253) }\end{array}$ \\
\hline source 22 & $\begin{array}{l}\text { Hofmeister, } \\
\text { R. H. }\end{array}$ & $\begin{array}{l}\text { Untersuchungen über die Witterungsverhältnisse von Lenzburg, Kt. Aargau, in: Neue } \\
\text { Denkschriften der allg. Schweizerischen Gesellschaft für die gesammten } \\
\text { Naturwissenschaften, Neuenburg, } 1847 \text {. }\end{array}$ & \\
\hline source 23 & $\begin{array}{l}\text { Deutscher } \\
\text { Wetterdienst }\end{array}$ & Phänologische Beobachtungen zur Winterroggenernte. & $\begin{array}{l}\text { Referat } \\
\text { Datenservice }\end{array}$ \\
\hline source 24 & $\begin{array}{l}\text { Pfister, } \\
\text { Christian }\end{array}$ & $\begin{array}{l}\text { Klimageschichte der Schweiz von 1525-1860 und seine Bedeutung in der Geschichte } \\
\text { von Bevölkerung und Landwirtschaft, Bd. 1, Haupt, Bern, } 174 \text { pp., } 1984 .\end{array}$ & \\
\hline source 25 & $\begin{array}{l}\text { Hänni, } \\
\text { Jakob }\end{array}$ & Tagebücher von Jakob Hänni, Bauer zu Grossafoltern, 1824-1869. & $\begin{array}{l}\text { Private property } \\
\text { of Hansjörg } \\
\text { Hauert, } \\
\text { Grossaffoltern }\end{array}$ \\
\hline source 26 & $\begin{array}{l}\text { Rothen, } \\
\text { Marcel }\end{array}$ & $\begin{array}{l}\text { Die Phänologischen Beobachtungen aus dem Schaffhauser Amtsblatt von 1876-1950, } \\
\text { BA Thesis, Institute of History (Section WSU), University of Bern, Bern, } 55 \text { pp., } 2009 .\end{array}$ & \\
\hline
\end{tabular}

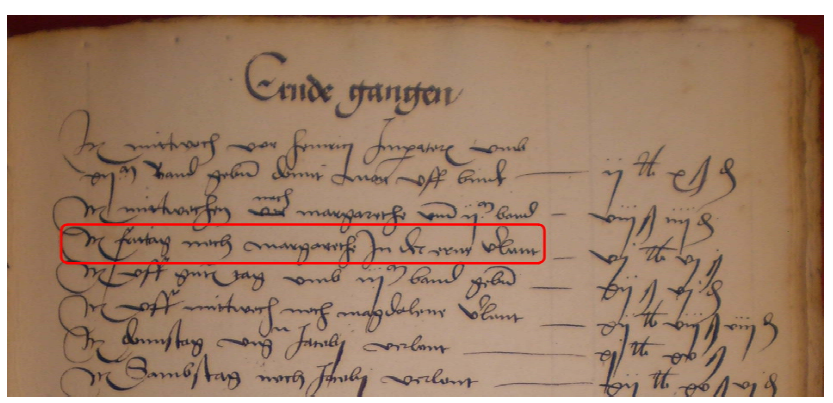

Fig. 4. "Item fritag nach margarethe in der ernt verlont" "also remunerated in harvesting (work) on Friday after Margaret (Day)" Extract form the book of expenditures of the hospital of Basel (from 1522); Staatsarchiv Basel-Stadt; Spital F12 (source1).

with more than 240 volumes of manuscript accounts for the period from 1454 to 1705 , often hardly legible, to be looked through for the 60 days from midJune to mid-August. Only a few books are missing altogether. Between 1631 and 1673, the accounts concerning grain harvest are not dated, and the date of first wage payment for the grain harvest is not given in some other books. The missing date of the earliest harvest in the outstanding warm anomaly of 1473 was complemented from coherent observations by regional chroniclers (Table 1; source 2). Moreover, rye (grain?) harvest dates from the chronicle of the Swiss reformer Heinrich Bullinger (1504-1575) (Table 1; source 3) and the diaries of the theologian Wolfgang Haller (1525-1601) (Table 1; source 4) were used to fill gaps in 1540 and 1555 .
- Tithe auction data (TAD) (Figs. 3, S2-S3/S5-S12 in the Supplement)

This kind of evidence, first analysed by Pfister (1979, 1992), is related to the payment of the tithe in kind, which had to be paid to the church. The grain tithe was usually paid within regions farmed according to the open-field system with three-year rotation, which was the prevalent agricultural system in most of Europe (Titow, 1965; Blum, 1978). Tithe owners were short of staff to monitor the correct payment due. Selling the collection of the grain tithe by auction to the highest bidder, usually to a member of the village elite, was a convenient solution. The tithe collector could keep the straw as a compensation for this work. An expert assessed the minimum value of the crop in every tithe district by order of the owner as soon as the grain was approaching maturity. If the minimum value was not offered in the auction, the owner initiated the collection of the tithe by his staff at the expense of the village. A representative of the owner presided over the auction, which ended in a popular festivity. The acceptance of the offer was laid down as proof in a written protocol. Tithe protocols, if they were dated, serve as a climatehistorical source. Where the elite of the emerging states adopted the reformation, as was the case in a number of Swiss cantons, they took over the church property and thus also became owner of the tithes. The supply of tithes ended when dues in kind were generally substituted by taxes in money in the early nineteenth century. In Switzerland, this became the case in the 1820s (Pfister, 1979, 1992). 
In the following we review the uncertainties involved in the use of TAD as a proxy for the starting date of grain harvest. Two major sources of uncertainty are discussed: first, the delay between the auction-date and the start of the harvest; and second, the mean altitude of the fields in every tithe district, which is needed for the homogenisation of the series. Sources are silent with regard to the time needed for the procedure of selling tithe by auction in relationship to the start of the harvest, because for the agents this fact was irrelevant. We have reason to assume that time lags were considerable given the fact that the representatives of the owners had to be present in many auctions in a short time. The actual start of the harvest, decided by the village community after the auction, depended on several factors such as the maturity of the crop, the observation of holidays and, most importantly, on weather conditions. Warm and sunny weather promoted the start of the harvest, whereas rainy weather led to a delay, because harvesting during wet spells bore the risk that the grain would not dry in time and rot in the fields. Tithe auction protocols refer to crops grown in the "winter field", where different varieties of winter crops were grown without distinguishing between rye and spelt, which were the main winter crops grown in the area of investigation (Miedaner, 1997). The second uncertainty concerns the mean altitude of the fields, which had to be assumed. The altitude of the respective village is often a poor approximation, as settlements were usually situated near brooks in the valley floor, whereas the respective crops in the classical three-course rotation were annually moved around the various fields situated at somewhat higher altitudes.

- Historic phenological data (HPD) (Figs. 3, S4/S13S17/S20 and S22 in the Supplement)

Data within modern phenological networks are gathered by observers instructed according to standardised guidelines. Prior to the establishment of networks, historical plant and animal phenological data (HPD) were laid down by amateurs at their sole discretion (e.g. Rutishauser et al., 2007). In this context, we need to distinguish, on the one hand, between scientifically-motivated early phenologists gathering observations on wild and domestic plants and, on the other hand, economically-motivated farmers laying down observations about the time of their agricultural work. Historical observations are not necessarily of lower quality. Schnelle (1955) concluded from his vast experience that the most accurate observations were gathered by motivated amateurs. However, most early observers were not aware of the importance to lay down the metadata (e.g. altitude, inclination, soil, plant varieties) of their plant observation. The lack of metadata is a major source of uncertainty when working with HPDs. Most historical phenological observations in Switzer- land were made before the 1830's. Subsequent series are rather short, scattered and hardly overlapping, so as to make the building up of a main series difficult and error-prone. The early nineteenth-century discontinuation of all-embracing climate observations in favour of exclusive measurement and quantification is a general trend in climate sciences (Jankovic, 2000), which severely hampers the application of calibration and verification techniques in historical climatology (Dobrovolný et al., 2009). Fortunately, a continuous series of rye harvest dates could be drawn for the years 1824 to 1869 from a recently discovered privately owned first class diary, in which the farmer and deputy Jakob Hänni (1801-1870) from the village of Grossaffoltern (Canton Bern) on the Swiss Plateau laid down a detailed account of the weather and his activities on the farm (Table 1; source 25). An initiative to systematically observe a set of phenological observations alongside meteorological network measurements was taken in Canton Schaffhausen from 1876 (Table 1; source 26). The evidence was published as an addendum to the official register of the Canton. About two dozen wild and cultivated plants and some wild animals, mostly birds, were observed until 1950, albeit with gaps. Moreover, two out of the three original stations stopped their observations from the early twentieth century (Rothen, 2009). The original observations are lost, making critical review of the data impossible. The grain harvest dates are not perfect but of good quality. The parson Johann Jakob Sprüngli (1717-1803) (Table 1; source 5) was the most outstanding historical phenologist in Switzerland. Sprüngli monitored the flowering of a hundred species of wild and domestic plants, of nine different fruit trees and the timing of different works in fields and meadows. Every spring he reported on the appearance of 28 different kinds of animals. Alongside he kept an instrumental weather diary in which he also noted down the formation and melting of snow-cover locally and also for the mountains visible from his house. Unfortunately, he had to move to another parish in his lifetime twice, i.e. from Zweisimmen (Bernese Oberland) to Gurzelen near Thun in 1766, and then to the village of Sutz near Biel in 1784, from where his series of rye harvest starting dates (Figs. 3 and S13 in the Supplement) originates (Pfister, 1984; Burri and Zenhäusern, 2009). The earliest series of HPD is provided by Anton Künzli (Table 1; source 6) who regularly listed the beginning of rye harvest in Winterthur (Canton Zürich) in his chronicle from 1611 to 1644 (Figs. 3 and S4 in the Supplement). The "Account Book" of the farmer Ulrich Steffen (Table 1; source 7) in Oberembrach (Canton Zürich) fills some gaps in the long period from 1816 to 1873 (Figs. 3 and S16 in the Supplement). A major uncertainty in using HPDs concerns the applied hand-harvesting technique. The scythe, originally developed for mowing grass, was 
in some cases during an early age used for reaping grain in place of the traditional sickle, namely from the late Mediaeval period in Holland and England (Pribyl et al., 2011) and subsequently in other places on the continent (da Costa, 1763; Tschiffeli, 1762). The use of the scythe "allowed for a quicker and less work-intensive harvest process, but increased waste and loss through shedding" (Pribyl et al., 2011). During the nineteenth century, it became usual practice to cut grain by means of the scythe at an earlier stage of maturity, giving an eight- to ten-day longer cutting season and thus reducing the risks of shedding (Collins, 1969), The breakthrough of the new reaping practice was achieved during the second half of nineteenth century, when grainprices declined and labour became scarce and expensive (Collins, 1969; Dubler, 2011).

- Phenological network observations (PNO) (Figs. 3, S18-S19/S21/S23-S25 in the Supplement)

The data situation in Switzerland between 1825 when TADs were not available anymore, and 1951 when the Swiss phenological observations network was founded, is weak. Germany, in contrast, has a long tradition of phenological network observations. The Historic Phenological Database (HPDB) of the German Meteorological Service (DWD) contains about 375000 plant phenological observations, originating from 1460 places in about 80 different regions. HPDB archived more than 500 species of plant observations between 1530 and 1950, whereas by far most of them originate from 1880 until 1941. Gathering phenological observations became mandatory for the observers of the German Meteorological Service in 1936; and such efforts continued to be made, disregarding interruptions during World War II and its aftermath, in both parts of the divided country beyond reunification (DWD, 1991). The observation programme is divided into three main groups: wild plants (1), crops (2), fruit-trees and vines (3). Observations are implemented after standardised manuals that include strict instructions (e.g. the observed place of growth from single plants shall be as representative as possible for the whole area of observance, or observed plants shall not differ more than $50 \mathrm{~m}$ of the mean elevation of the designated area of observance, or observations must always be done on the same plant or field during the whole vegetation period and once chosen observation objects shall be observed for as many years as possible, etc.) (DWD, 1991). Crop observations, in particular concerning winter rye (secale cereale), are a matter of special interest for this study. The manual defines nine different observation categories for winter rye. The last - "harvest" - is undeniably easy to discern, whereas observations about physiological stages, like maturity, are difficult clearly identify (DWD, 1991; Allen and Lueck, 2002). The introduction of the com- bine harvester thresher radically changed grain harvesting. A combine requires grain to be ripe 7 to 10 days before cutting (Allen and Lueck, 2002). This significantly differs from manual harvests or harvest with grain harvest binders, both depending on an earlier physiological stage of the crop, being more or less around "yellow ripeness" (Gelbreife). Statistical tests clearly demonstrated that correlations between temperature and date of harvest significantly weaken if observations after the 1970s are included. This may be explained with the difference of harvesting methods (manual or harvest by binders vs. harvest by combines), the introduction of hybrid sorts and the fact that, since the 1970s, a multitude of completely new breeds exist that were specially bred for a wide range of different requirements (e.g. earlier achieving the stage of ripeness to avoid heat and drought stress of late summer, etc.).

Figure 1 displays the spatial location of the series and their approximate altitude. The WPD series (1) and the TAD (10) and HPD series (8) are located in Switzerland, whereas the PNO series (6) originate from south-western Germany. The WPD Basel series and the majority of the PNO from southwest Germany originate from places situated below $400 \mathrm{~m}$ a.s.l. Most of the TAD and HPD series from the Swiss Plateau region were obtained from places situated at altitudes between 400 and $550 \mathrm{~m}$ a.s.l. Three series are situated above $550 \mathrm{~m}$ a.s.1.

\section{Generation of a homogenised Basel WGHD series}

In the previous section it was shown that the WGHD evidence consists of a number of partial series involving four different types of data. This section addresses the issue of merging these partial series into a 517-yr long main series, which is named Basel WGHD series after its longest and most ancient part. The task involved correcting the evidence for dating style, data type and altitude. Figure 3 presents the composition of the Basel WGHD series distinguishing between five sections of different data quality and coverage separated with vertical lines. Metadata of the partial series are contained in Table 2. Correlations were calculated from partial original series, most of which do have a sufficient overlap of $>10$ values and significantly correlate between $R^{2}=0.4$ and 0.8 (others are marked in red) (Supplement).

With regard to the composition of the Basel WGHD series, 5 periods are distinguished

- The first 103 yr (1454-1556) of the series are exclusively covered by the Basel WPD complementing missing data with sporadic HPDs.

- The second period (1457-1662) includes the long gap in the Basel WPD series which was complemented to a large extent with 2 TAD and 1 HPD series. 
Table 2. Metadata of partial WGHD series (WPD, TAD, HPD and PNO series). WPD = Wage Payment Data; TAD = Tithe Auction Data; $\mathrm{HPD}=$ Historical Phenological Data; $\mathrm{PNO}=$ Phenological Network Observations.

\begin{tabular}{|c|c|c|c|c|c|c|c|c|c|c|c|}
\hline series & type & coverage & location & alt. & $n$ & $\begin{array}{c}\varnothing \\
\text { DOY }\end{array}$ & std. & $\begin{array}{c}\text { corr } \\
\text { with } \\
\text { S1(R2) }\end{array}$ & $\begin{array}{c}\mathrm{p} \\
\text { value }\end{array}$ & $\begin{array}{c}n \\
\text { (overlap) }\end{array}$ & source \\
\hline $\mathrm{S} 1$ & WPD & $1454-1705$ & Basel & 320 & 164 & 201 & 7.9 & - & - & - & Table 4; source 1 \\
\hline $\mathrm{S} 2$ & TAD & $1557-1812$ & Büren (2) & 430 & 135 & 194 & 6.5 & 0.202 & 0.01 & 40 & Table 4; source 24 \\
\hline S3 & TAD & $1595-1813$ & St Pantaleon & 520 & 102 & 199 & 6.4 & 0.585 & 0.01 & 30 & Table 4; source $17-21$ \\
\hline S4 & HPD & $1611-1640$ & Winterthur & 439 & 30 & 192 & 7.8 & 0.397 & 0.05 & 11 & Table $4 ;$ source 24 \\
\hline S5 & TAD & $1640-1825$ & Erlach & 550 & 171 & 197 & 6.2 & 0.483 & 0.01 & 29 & Table 4 ; source 24 \\
\hline S6 & TAD & $1640-1825$ & Illnau & 510 & 181 & 196 & 6.5 & 0.477 & 0.01 & 29 & Table 4 ; source 24 \\
\hline S7 & TAD & $1651-1825$ & Frienisberg & 530 & 162 & 196 & 5.9 & 0.564 & 0.01 & 29 & Table 4 ; source 24 \\
\hline S8 & TAD & $1653-1825$ & Andelfingen & 370 & 168 & 193 & 6.7 & 0.418 & 0.01 & 29 & Table 4; source 24 \\
\hline S9 & TAD & $1658-1825$ & Sursee & 500 & 163 & 194 & 6.1 & 0.409 & 0.01 & 29 & Table 4 ; source 24 \\
\hline S10 & TAD & $1663-1825$ & Büren (1) & 470 & 156 & 196 & 5.9 & 0.468 & 0.01 & 27 & Table 4 ; source 24 \\
\hline S11 & TAD & $1663-1825$ & Fraubrunnen & 505 & 158 & 195 & 6.7 & 0.564 & 0.01 & 29 & Table 4; source 24 \\
\hline S12 & TAD & $1663-1825$ & Landshut & 470 & 158 & 195 & 6.6 & 0.548 & 0.01 & 27 & Table 4 ; source 24 \\
\hline S13 & HPD & $1788-1801$ & Sutz & 450 & 13 & 204 & 7.1 & - & - & - & Table 4; source 5 \\
\hline S14 & HPD & $1815-1848$ & Husen & 460 & 23 & 202 & 9.0 & - & - & - & Table $4 ;$ source 7 \\
\hline S15 & HPD & $1816-1844$ & Lenzburg & 400 & 21 & 200 & 10.4 & - & - & - & Table 4 ; source 22 \\
\hline S16 & HPD & $1816-1873$ & Oberembrach & 460 & 15 & 199 & 9.2 & - & - & - & Table $4 ;$ source 7 \\
\hline S17 & HPD & $1824-1869$ & Grossaffoltern & 511 & 46 & 202 & 5.9 & - & - & - & Table 4 , source 25 \\
\hline S18 & PNO & $1836-1918$ & Friedrichshafen & 408 & 41 & 202 & 7.2 & - & - & - & Table 4 ; source 23 \\
\hline S19 & $\mathrm{PNO}$ & 1842-1909 & Schopfloch & 764 & 43 & 219 & 8.1 & - & - & - & Table 4; source 23 \\
\hline S20 & HPD & $1849-1950$ & (Unter-) Hallau & 421 & 76 & 192 & 5.9 & - & - & - & Table 4; source 26 \\
\hline $\mathrm{S} 21$ & PNO & $1859-1911$ & Ochsenhausen & 614 & 20 & 211 & 6.4 & - & - & - & Table 4 ; source 23 \\
\hline S22 & HPD & $1876-1915$ & Lohn & 636 & 31 & 210 & 6.9 & - & - & - & Table 4; source 26 \\
\hline S23 & PNO & $1951-1970$ & Weil am Rhein & 280 & 19 & 203 & 6.8 & - & - & - & Table 4 ; source 23 \\
\hline S24 & PNO & $1951-1968$ & Merdingen & 193 & 17 & 198 & 5.4 & - & - & - & Table 4 ; source 23 \\
\hline $\mathrm{S} 25$ & PNO & 1955-1969 & Allensbach & 400 & 12 & 204 & 7.8 & - & - & - & Table 4; source 23 \\
\hline
\end{tabular}

- For the third period (1663-1869), 10 series of TADs, overlapping with the WPD series until 1705, and 3 series of HPDs are available. The gap of TADs between 1798 and 1801, related to the abolishment of feudal dues during the short-lived Helvetic Republic installed by the French Revolutionary armies (Hughes, 1975), was filled by the first class HPD observations made by the parson Johann Jakob Sprüngli (Table 1; source 5) (Figs. 3 and S13 in the Supplement).

- In the fourth period (1870-1950), the main series hinges in some part on isolated partial series of HPDs carried out by amateurs who often did not provide the metadata needed for assessing data quality, and in some part on high quality early PNOs from the German Historic Phenological Database (HPDB).

- Section 5: (1951-1970) is completely covered by PNOs gathered by standardised methods.

In general, the Basel WGHD series is well documented for the pre-instrumental period, whereas it is of somewhat lower quality from 1870 to 1950 , i.e. during a considerable part of the instrumental period. This shortcoming affects the results of temperature estimates using the approach of calibration and verification.

The following paragraph describes the adaptations required to put the partial series on an equal level. This task concerns dating style, altitude and, in the case of TADs, estimating the start of the harvest after the auction date.

\subsection{Homogenisation of dating style}

Prior to 1559, dating in the Basel WPD series is given with reference to the ruling Saint of the particular day. The procedure is explained from the example of 1522 (Fig. 4). The reference "Friday after Margaret Day" is decoded by consulting the chronology handbook by Hermann Grotefend (Grotefend, 2007). The first step is to look up the date of the Saints Day. In Basel, "Margaret Day" (Margarete) was celebrated on 15 July. In the second step, the Easter date of the year of interest, in 1522 it was 20 April, is determined using the algorithmic Gaussian Easter Formula (Gauss, 1800). The Saints Day in question is looked up in the Easter table for the corresponding year. In 1522, Margaret Day was on a Tuesday. The subsequent Friday, on which the grain harvest started in Basel, was thus 18 July (DOY 199). From 1559, the current 
system of months and days was used. Dates before 1700 originating from protestant territories (Figs. 3 and S1, S2, S4-S8, S10-S13 in the Supplement) need to be redated from the Julian to the Gregorian calendar style by adding ten days, whereas series from catholic St Pantaleon (Figs. 3 and S3 in the Supplement) and Sursee (Fig. 3) are altogether dated in Gregorian style.

\subsection{Type of grain}

The 103 entries in the Basel hospital accounts explicitly refer to rye being first harvested, while in 131 cases the source just mentions "remunerated for harvesting work". As there is no difference between the statistics obtained for the two denotations (Table 3), it can be assumed that both are equivalent. PNO series clearly have to be rated as the most reliable series. The closeness of the statistical properties of the compiled Basel WPD series to the just neighbouring PNO Weil am Rhein observations, as well as to all other PNO series (especially considering mean harvest dates and standard deviations), furthermore supports the supposition of equivalence of both notations and approves the reliability of WPDs.

\subsection{Homogenisation of data type}

Figure 5a demonstrates that Basel WPD series nicely fits into the distribution of altitude depending mean harvest dates of the high quality PNO observations. Uncertainties concerning TAD- and HPD series, however, need a somewhat more accurate consideration, as the means of these series do not exactly match those of the reliable PNO/WPD series. Figure $5 \mathrm{~b}$ shows that differences between HPD and PNO/WPD series are not big (light green circles); differences between TAD (blue crosses) and PNO/WPD series, by contrast, are somewhat more important. To homogenise TAD and HPD series to the reliable PNO/WPD series, it was necessary to add +13 days to TAD and +6 days to HPD series (Fig. $5 b$ ). The difference of 13 days between TAD and PNO/WPD series may be partly explained by the fact that TADs represent another kind of proxy. Tithe auctions needed to be held before the harvest took place. It is not known how much time between the auction and the actual harvest usually passed, as tithe auction protocols remain silent in this regard. Assuming an average delay between tithe auction and the actual harvest initiation of about 7 days, the same difference as between HPD and PNO/WPD turns out (6 days). In doing so, uncertainties about the actual harvest initiation after the auction should not be overestimated, given the strong relationship between a sample of 41 local TAD series from 1611 to 1825 and Basel spring-summer (MAMJJ) temperatures of $r=0.86$ (Pfister, 1979). The difference of 6 days between HPD and PNO/WPD series may be related to the change from the sickle to the labour-saving scythe during the nineteenth century (see Sect. 2.3) and/or to differences in ripeness. According to V. Michel (personal communica-
Table 3. Similar statistical properties of two different notations, most probably describing the same agricultural activity.

\begin{tabular}{lll}
\hline & $\begin{array}{l}\text { notation } \\
\text { "rye } \\
\text { harvest" }\end{array}$ & $\begin{array}{l}\text { notation } \\
\text { "waged in } \\
\text { harvest" }\end{array}$ \\
\hline $\begin{array}{l}\text { Mean } \\
\text { (DOY) }\end{array}$ & 199.71 & 199.81 \\
\hline $\begin{array}{l}\text { Standard } \\
\text { Deviation } \\
\text { (Days) }\end{array}$ & 8.61 & 6.79 \\
\hline $\begin{array}{l}\text { Minimum } \\
\text { (DOY) }\end{array}$ & 177 & 183 \\
\hline $\begin{array}{l}\text { Maximum } \\
\text { (DOY) }\end{array}$ & 227 & 215 \\
\hline$n$ & 103 & 131 \\
\hline
\end{tabular}

tion, January 2011), as well as E. Zechner (personal communicaiton, January 2011) - both being renowned experts - such differences of ripeness are still observed today and may be explained by a multitude of mutual cumulative reasons, like soil type, differences in slope, grain variety, sowing time, manuring, insulation etc. (e-mail communication 18-20 January 2011, Diepenbrock et al., 2005). By homogenising the HPD and TAD series with the above described method (TAD +13, HPD +6 days), a clear significant correlation $(r=0.92)$ between homogenised winter rye harvest series and altitude appears (Fig. 5c).

\subsection{Homogenisation of altitude}

In a last homogenisation step, the difference of altitudes needed to be "adapted" to the main Basel WPD series. Regarding the fact of such a strong correlation between altitude and time of harvest (Fig. 5c), this final homogenisation step could easily be done by linear regression. Last but not least, all available figures needed to be annually averaged. After having taken these homogenisation steps, we may speak from the Basel Winter Grain Harvest Date series (Basel WGHD).

\subsection{Calibration - verification}

The final Basel WGHD series was compared for the period 1774 to 1970 with the homogeneous HISTALP temperature series (Auer et al., 2007; Böhm et al., 2010), which yields monthly anomalies from the 1901 to 2000 average. The area of investigation is situated in the sub-region "Northwest" (Fig. 6; blue dots). Stepwise linear regression revealed that July temperatures were the most important factor, followed by June, May and March temperatures, which confirms the result of Pfister (1979). The substantial weight of 


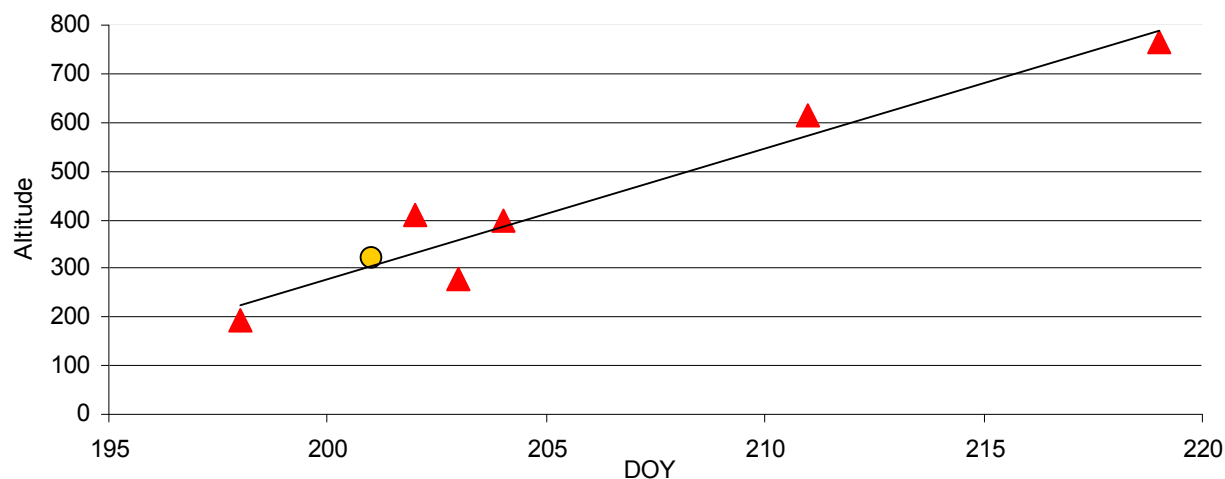
A Schopfloch (PNO)
a) $\Delta$ Merdingen (PNO)
a) $\bigcirc$ Basel (WPD)
A Ochsenhausen (PNO)
Allensbach (PNO)
Weil am Rhein (PNO)
PNO = Phenological Network Observations
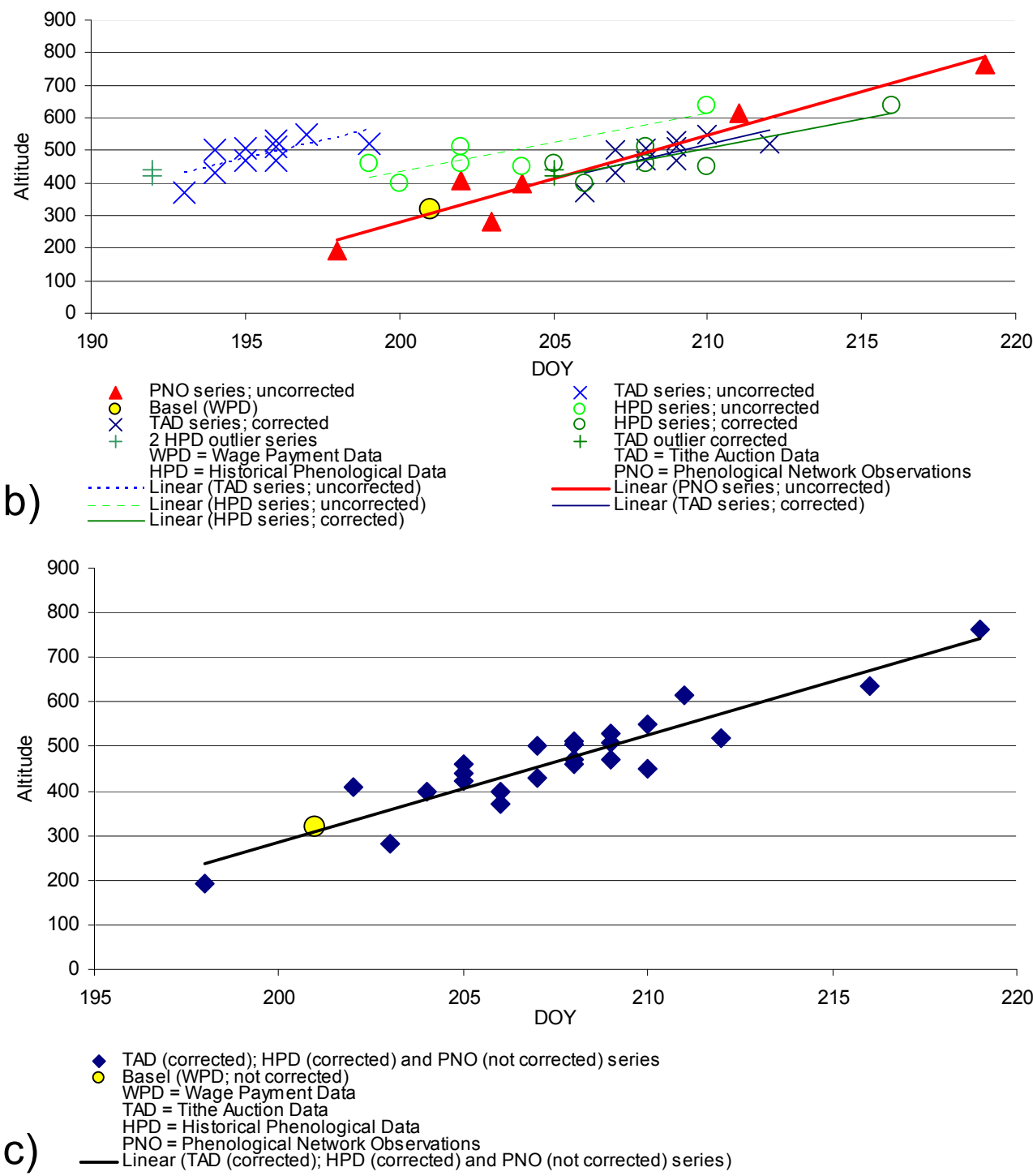

Fig. 5. (a) Basel WPD series and PNO series lying on the same altitude-depending linear trend. (b) Statistical correction of HPD and TAD series to the reliable PNO/WPD series. (c) Statistical correction of HPD and TAD series to the reliable PNO/WPD series. 


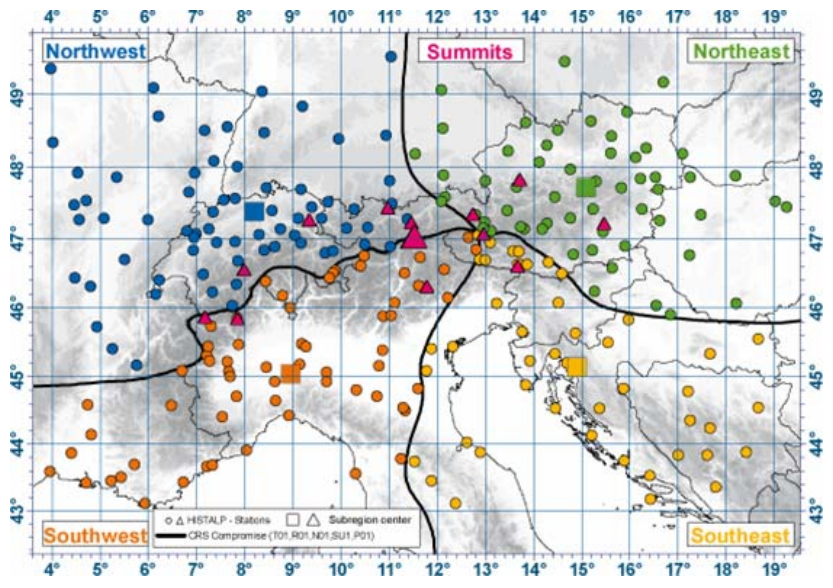

Fig. 6. HISTALP temperature anomalies from 1901-2000 averages; (Auer et al., 2007) blue dots (northwest stations); green dots (northeast stations); orange dots (southeast stations); red dots (southwest stations).

March temperature agrees with the fact that winter rye (secale cereale) actually grows during any warmed days of the winter, when sunlight temporarily brings the plant to above freezing (Diepenbrock et al., 1999; Wikipedia, 2011; http: //en.wikipedia.org/wiki/Rye). Calibration was done during 1774-1824, the first 50 yr of HISTALP temperature anomalies available (Fig. 7a). The result of $r=0.78$ includes a pronounced outlier in March, 1785, when average temperatures were $6.9^{\circ} \mathrm{C}$ below the twentieth century mean (Auer et al., 2007). Verification was done from 1920-1970 (Fig. 7b).

The calibration and verification procedure applied for the two sub periods 1774-1824 and 1825-1970 confirmed the high reconstruction skill of WGHD, which explains $52 \%$ $(r=0.75)$ of the variance of mean March-July temperature in the verification period (1920-1970) (Fig. 7b). Standard Error of Estimate is $0.6^{\circ} \mathrm{C}$. These reconstructed temperature anomalies needed to be further adjusted for a difference in means of $+0.3{ }^{\circ} \mathrm{C}$ between the calibration periods of HISTALP (1901-2000) and ours (1774-1824). The bias was corrected by subtracting this difference from the reconstructed series of spring-summer temperatures. It follows from the reconstruction that a difference of nine days of the Basel WGHD series corresponds to a change of approximately $1^{\circ} \mathrm{C}$ in March-July temperature anomalies.

\section{Result}

The result is a reconstruction of 517-yr mean March-July temperature anomalies, based on 25 homogenised grain harvest date series from north-western Switzerland and southwestern Germany (1454-1970) (Fig. 8). Figure 8 shows an 11-yr high pass filter of reconstructed temperature anomalies. Confidence bounds are drawn on a $\pm 2 \times$ Sigma threshold. The "hockey stick", often seen in temperature recon- structions does not appear here, as the youngest warming trend after the 1970s is not included in the WGHD temperature anomalies reconstruction. For validation reasons we should cross check extremes in time series of proxy data, be it out of natural or societal archives, with narrative data. It has been shown that chroniclers frequently referred to phenological observations to support their descriptions of extreme temperature anomalies in the summer half-year (AMJJAS). The subsequent paragraph presents such descriptive evidence for the positive and negative extremes.

\subsection{Warm extremes}

The earliest harvests in the instrumental period (from 1774) are documented in ascending order for (DOY 186:1822/DOY 187:1868/DOY 188:1846/DOY 189:1842/DOY 190:1862/DOY 191:1811, 1835, 1934). The very early harvests of 1811,1822 and 1846 were all connected to spring-summer intervals in which every single month from March to July was above the twentieth century mean resulting in cumulative warm anomalies of $12.0^{\circ} \mathrm{C}$ in $1822,11.4^{\circ} \mathrm{C}$ in 1811 and $7.8^{\circ} \mathrm{C}$ in 1846 for the entire interval. In 1868 a cool spring was overcompensated with an extremely warm interval in May and June resulting in a cumulative warm anomaly of $3.7^{\circ} \mathrm{C}$. However, the early harvest in 1842 documented from two places is not supported with corresponding instrumental evidence (Auer et al., 2007). In 1862 and 1934, all months except June were warm resulting in a cumulative warm anomaly of $5.4 \circ \mathrm{C}$ and $4.6^{\circ} \mathrm{C}$. In 1835 the slightly too cold March and April are overcompensated with warm May, June and July temperatures of $2.4^{\circ} \mathrm{C}$. The rye harvest date for 1947 , the warmest summer in the twentieth century, is missing for both post-war Germany and Switzerland.

The earliest data in the pre-instrumental period are documented in ascending order for 1473: DOY 184; 1616: DOY 185 ; 1540: DOY 186; 1483: DOY 188; 1686: DOY 189; 1611, 1645, 1718: DOY 190: 1603; 1631: DOY 191.

All of them are connected to narrative documentary evidence on warm springs and summers. The grain harvest in 1473 was the earliest of the $517 \mathrm{yr}$ long investigation period. Chroniclers report full blossoming of (cherry) trees "in February" (Julian Style), i.e. around 9 March in Gregorian style (Table 1; source 2), which points to extremely high late winter temperatures. An outstanding vegetation advance of three to four weeks was maintained until late summer, concluding from the beginning of grain harvest, the maturity of (early burgundy?) grapes in early July (Table 1; source 8 ) and the general onset of vintage in early September. The year was extremely dry concluding from reports of water shortages and forest fires (Table 1; source 9). June and July 1616 were extremely hot and almost without rain, after a warm spring, throughout central Europe (Pfister, 1999; Glaser, 2008). Weather in 1540 was outstandingly 
Calibration 1774-1824

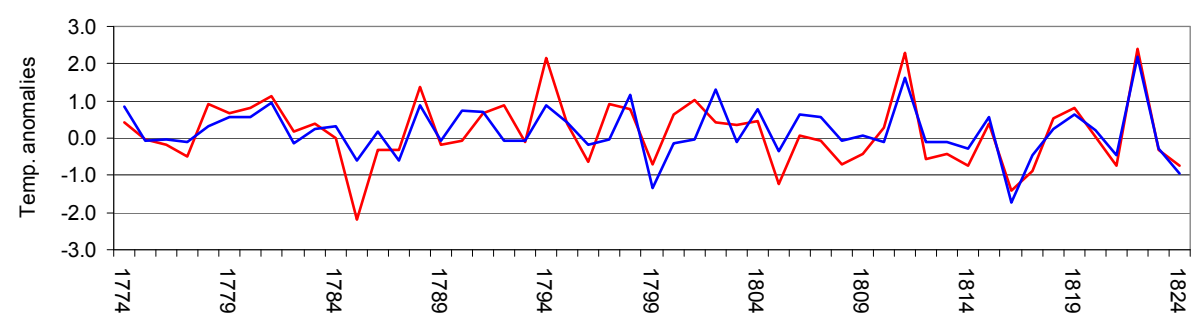

a) - T-HISTALP March-July 1774-1824 - Basel GHD 1774-1824 correlation 0.78, p value 0.01

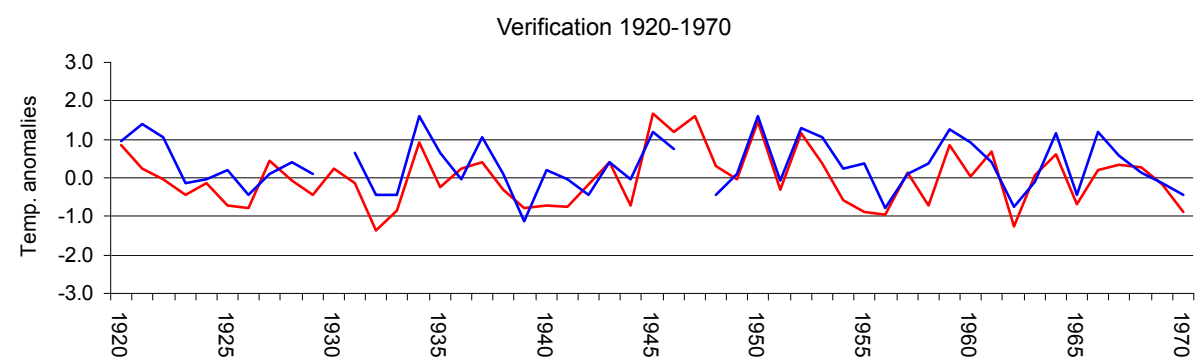

b) - - T-HISTALP March-July 1920-1970 - Basel GHD 1920-1970 correlation 0.75 , $p$ value 0.01

Fig. 7. (a) Calibration (1774-1824) and (b) verification (1920-1970) of Basel WGHD series with HISTALP temperature anomalies (mean March-July temperatures); Standard Error of Estimate $=0.6^{\circ} \mathrm{C}$.

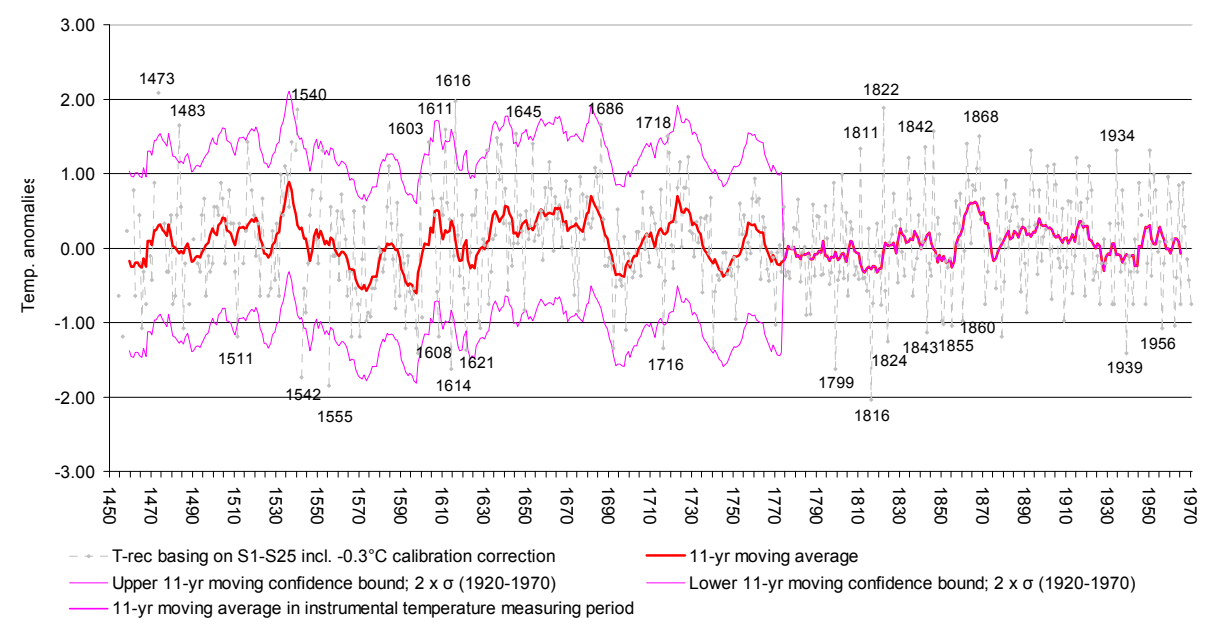

Fig. 8. Mean March-July temperature anomalies reconstruction basing on Basel WGHD series 1454-1970.

hot and dry from March until Christmas. Water shortages and forest fires were frequent. The vegetation was more than three weeks advanced (e.g. Pfister, 1999; Glaser et al., 1999). Spring in 1483 was slightly cooler than in 1473 , to conclude from the appearance of florescence in vines at the end of March (Table 1; source 10). The grain harvest in Basel began four days later than in 1473. Ripe (early burgundy?) grapes were sold in Zürich on 20 July (Table 1, source 11).

The spring-summer interval in 1603 , according to the Luzern scientist Renward Cysat, was extremely warm and dry with frequent southerly winds leading to water shortages, even in the Alps (Table 1; source 12). Likewise, in 1631 and in 1718, the entire interval from March to July was warm and dry, also, disregarding a cold phase in March, in 1645. The early harvests in 1611 and 1686 are primarily connected to a warm and dry spring (data in Pfister, 1999).

\subsection{Cold extremes}

The latest harvests in the instrumental period (from 1774) are documented in descending order for 1816: DOY 222; 1799 : DOY 218; 1939: DOY 216; 1843, 1824: DOY 215; 1860, 1855: DOY 214; 1956: DOY 213. 
The harvest in 1816, the famous year without a summer, was the latest in the past $657 \mathrm{yr}$. Temperatures in that year were substantially below the 20th century mean in every single month from March to July, resulting in a cumulative negative anomaly of $7.1^{\circ} \mathrm{C}$ for the entire interval. The very late harvests in 1799, 1824, 1843, 1855, 1860, 1939 and 1956 are connected to 3-5 cold months during the March to July interval without compensation of a warm month, disregarding the warm April in 1939. The resulting cumulative cold anomalies are, in descending order: $6.3^{\circ} \mathrm{C}(1843), 5.8^{\circ} \mathrm{C}(1860)$, $4.8^{\circ} \mathrm{C}(1956), 4.1^{\circ} \mathrm{C}(1855), 3.7^{\circ} \mathrm{C}(1824), 3.6^{\circ} \mathrm{C}(1799)$, and $3.0^{\circ} \mathrm{C}(1939)$.

The latest harvests in the pre-instrumental period are documented in descending order as follows: 1555 DOY 220; 1542: DOY 219; 1614: DOY 218; 1621: DOY 216; 1716 : DOY 215; 1511, 1608: DOY 214. The date for 1555 is drawn from the diary of the reformer Heinrich Bullinger (Table 1; source 3). April, June and particularly July were cold and very wet in that year. The spring of 1542, in particular April and May, was extremely cold in Switzerland, concluding from a 4-week delay in the unfolding of beach leaves (Table 1; source 13). The vegetation delay even extended till early August, when the vines finally came into bloom (Table 1, source 3). June and July were also very cold in Germany (Dobrovolný et al., 2010). In 1614, snow cover in the Swiss Plateau, after an extremely long and cold winter, did not melt before early April (Table 1; source 14). This observation agrees with the report of another chronicler repeatedly mentioning drift ice in small rivers during March (Table 1; source 6), which points to extremely low temperatures, possibly as low as in March 1785 (Auer et al., 2007). Unlike in 1785, May and June were cold in Switzerland (Dobrovolný et al., 2010, which accounts for the extreme delay of the rye harvest). After a cool and rainy period in May and June 1621, July became a full winter month on the alpine meadows, concluding from two weeks of continuous snow cover (Table 1; source 15; Table 1; source 16). Conditions in spring 1511 are not known, but June and July were cold and wet (Pfister, 1999). In 1608, snow-melt in the Alps at altitudes between 1000 and $2000 \mathrm{~m}$ was 3 to 4 weeks delayed according to the Luzern scientist Renward Cysat, which points to very low spring-summer temperatures (Table 1; source 12). In 1716, all months from March to July were very cold (Pfister, 1999). In conclusion, cross-checking the extremes with reports from narrative sources, disregarding the case of 1842, yielded conclusive results.

\section{Discussion}

The 11-yr moving average curves of Basel WGHD and Burgundy GHD (Chuine et al., 2004) show quite similar courses (Fig. 9a). Discrepancies emerge in the second half of the nineteenth century.
These discrepancies in the "modern period" disappear if moving 11-yr averages of Basel WGHD- and Swiss Plateau GHD series (Meier et al., 2007) are being compared (Fig. 9b). On the other hand, this GHD series remains on a "warm" level during the well known period of long term cooling after 1550 involving far reaching glacier advances (Fig. 9b). This inconsistency sheds strong doubt on the reliability of the data for this interval of time.

Congruities between Basel WGHD and geographically far-off Hungary temperature anomalies (Kiss et al., 2011) are astonishingly well, even though discrepancies in the "modern period" reappear (Fig. 9c). Weakest congruities of 11yr moving averages exist between Basel and Czech Republic WGHD based temperature series (Mozny et al., 2011) (Fig. 9d). This may be explained by distance and more continental influenced climate in Czech Republic. Kiss et al. (2011) furthermore explain the quite weak congruities between Hungarian and Czech reconstructions with the fact that Mozny et al. (2011) only include MAMJ temperatures, whereas Kiss et al. (2011) - like our reconstruction - additionally includes July, which is according to the stepwise linear regressions in both cases the most influential month. The discrepancies in 17th century are caused by the Thirty Years War and its aftermath (Mozny et al., 2011). As all four comparisons more or less obviously show a cooler nineteenth century we have to assume the Basel WGHD reconstruction to be weak in that period, which clearly corresponds to the low availability of data during that period.

The 31-yr moving correlations between Basel WGHD temperature anomalies as well as temperature reconstructions from the Czech Republic (Mozny et al., 2011), Hungary (Kiss et al., 2011), Germany (Dobrovolný et al., 2010), Austria (Maurer et al., 2009), France (Chuine et al., 2004) and Switzerland (Meier et al., 2007) also show quite good results (Fig. 10). Nevertheless the 31-yr moving correlations also reveal some weaknesses of the Basel WGHD series. There is a clear drop in moving correlations for the period between 1479 and 1522. As three series overlapping with the Basel WGHD series (GHD Basel hospital; GHD Burgundy and WGHD Czech Republic) show this drop in the corresponding period we have to assume the problem is attributable to our series, even though moving correlations with the temperature index for Germany remains high during that time. The drop of moving correlations of the Austrian temperature reconstruction between 1541 and 1580 seems to be caused by the Austrian series as all other temperature reconstructions show good correlations during this period and the authors of the Austrian temperature reconstruction also stated that there were significant changes of practices in viniculture which influenced their data during that time (Maurer et al., 2009). The drastic drop of correlations between the Czech and our temperature reconstruction in the 17th century is associated with the effect of the Thirty Years War (1618-1648) that drastically affected the rural workforce and the overall quality of agricultural practice and led to longer term economic 


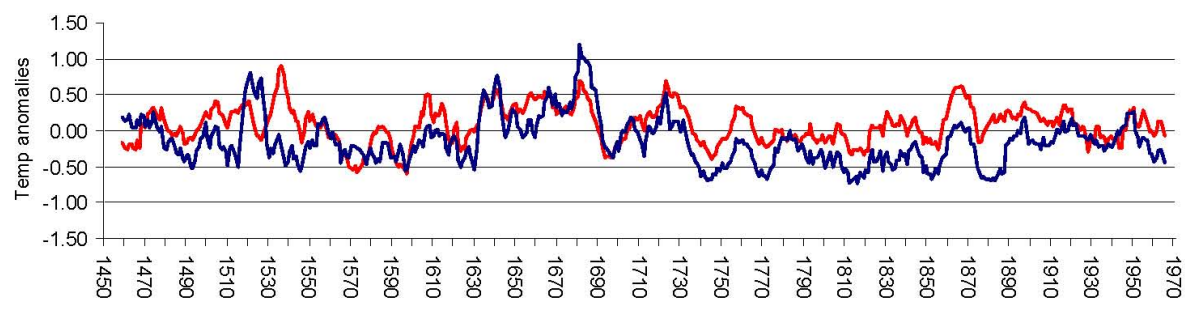

a) -11-yr mov av. T-rec Wetter and Pfister (this paper) — -11-yr mov av. T-rec Chuine et al. (2004)

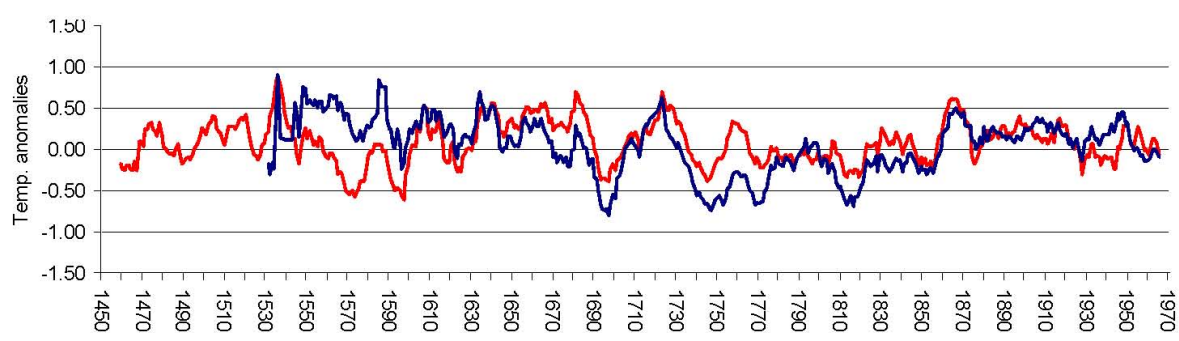

b) -11-yr movav. T-rec Wetter and Pfister (this paper) — 11-yr mov av. T-rec Meier et al. (2007)

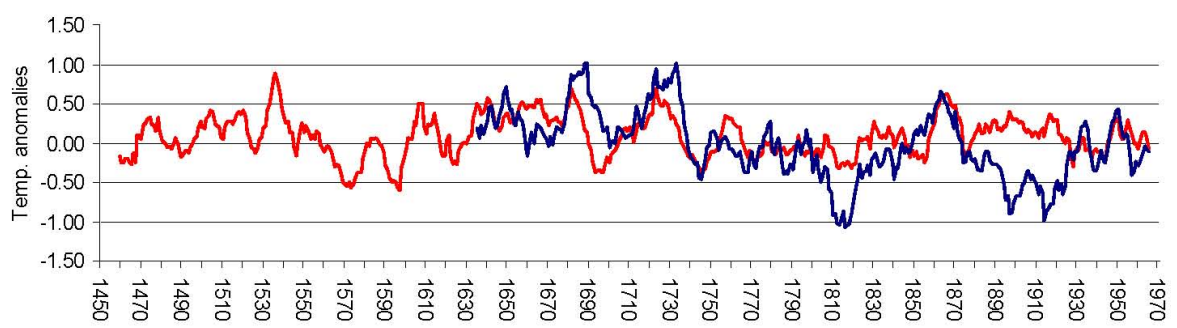

C) -11-yr movav. T-rec Wetter and Pfister (this paper) —11-yr mov av. T-rec Kiss et al. (2011)

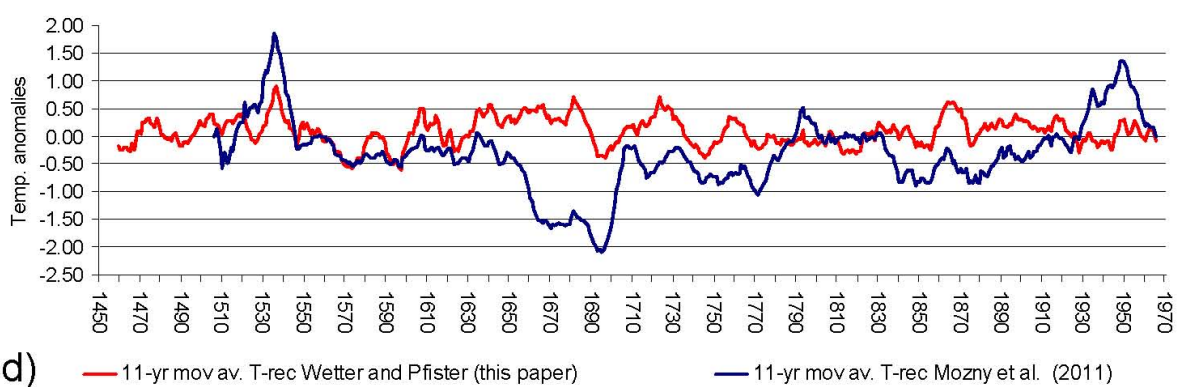

Fig. 9. (a) 11-yr moving averages of Basel WGHD (red) and Burgundy GHD reconstructed temperature anomalies. (b) 11-yr moving averages of Basel WGHD (red) and Swiss Plateau GHD reconstructed temperature anomalies. (c) 11-yr moving averages of Basel WGHD (red) and Hungary temperature anomalies reconstructed temperature anomalies. (d) 11-yr moving averages of Basel WGHD (red) and Czech Republic WGHD reconstructed temperature anomalies.

disruption and poverty in the Czech Lands (Mozny et al., 2011) in contrast to the neutral Swiss Confederation. The reason for the parallel drop of correlations between 1740 and 1760 with the Austrian, Czech and Hungarian temperature reconstructions and the steady improvements between 1761 and 1809 has to be left unanswered, as the Swiss Plateau Region and Burgundy, on the other hand, correlate best during this same period (1740-1809). The slow drop of correlations between 1810 and 1869 of all temperature reconstructions (except the Swiss Plateau temperature series) is clearly caused by our temperature reconstruction due to the weak data availability for the period after 1825 in Switzerland. The improvements of moving correlations of all temperature reconstructions in the 1880s, however, clearly correlate with the better quality of phenological data in Switzerland and south-western Germany. Best overall correlations are achieved with geographically neighbouring temperature reconstructions, and correlations furthermore clearly decrease corresponding to increasing distances (Table 4). 


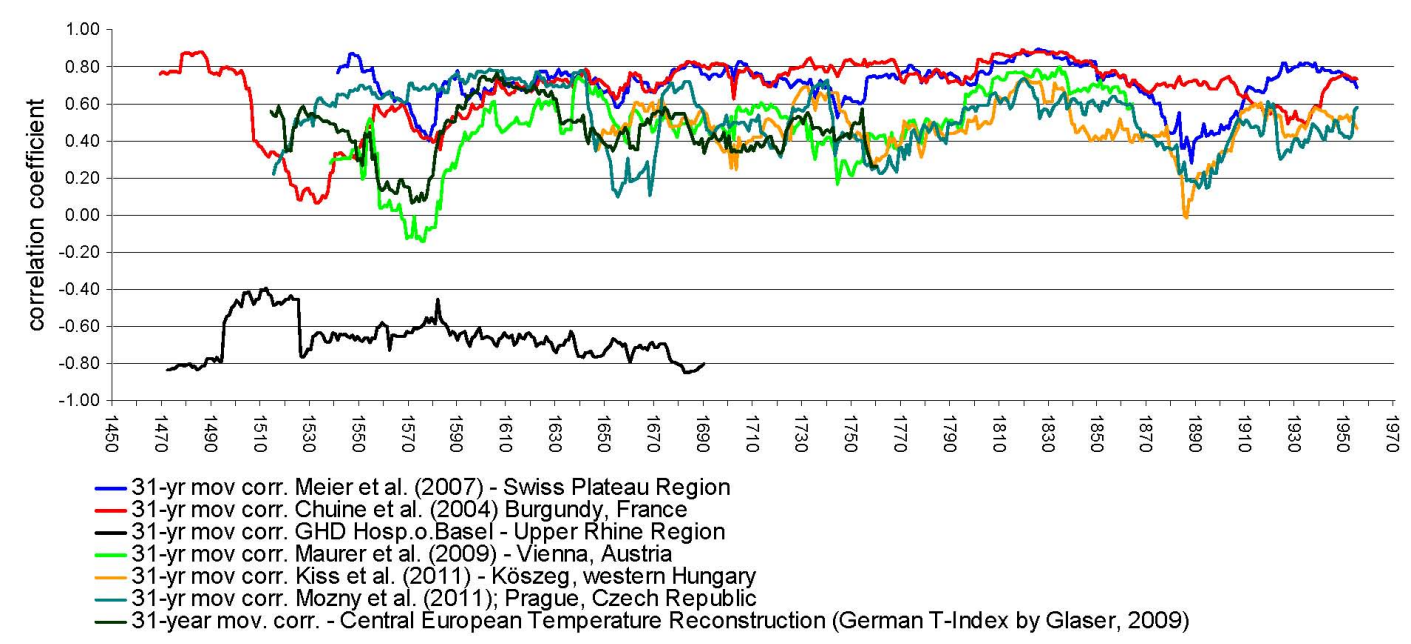

Fig. 10. 31-yr moving correlations between Basel WGHD- and other European temperature reconstructions Swiss temperature reconstruction by Meier et al. (2007) French temperature reconstruction by Chuine et al. (2004) Austrian temperature reconstruction by Maurer et al. (2009) Hungarian temperature reconstruction by Kiss et al. (2011) Czech Republic temperature reconstruction by Mozny et al. (2011) German temperature reconstruction (T-Index by Glaser) in Dobrovolný et al. (2009).

Table 4. Overall correlations between Basel WGHD temperature anomalies reconstruction and temperature reconstructions from Switzerland, Germany, Austria, France, Hungary and Czech Republic.

\begin{tabular}{|c|c|c|c|}
\hline Type of series & Origin & Correlation & Authors \\
\hline $\begin{array}{l}\text { Grape harvest } \\
(1480-2006)\end{array}$ & Swiss Plateau & $\begin{array}{l}r=0.67 \\
p=0.01\end{array}$ & $\begin{array}{l}\text { Meier et al. } \\
(2007)\end{array}$ \\
\hline $\begin{array}{l}\text { Grape harvest } \\
(1444-1705)\end{array}$ & $\begin{array}{l}\text { Basel, books of } \\
\text { expenditures } \\
\text { of Basel } \\
\text { hospital }\end{array}$ & $\begin{array}{l}r=-0.65 \\
p=0.01\end{array}$ & $\begin{array}{l}\text { Wetter et al. } \\
\text { (unpublished) }\end{array}$ \\
\hline $\begin{array}{l}\text { Grape harvest } \\
(1370-2003)\end{array}$ & $\begin{array}{l}\text { France } \\
\text { (Burgundy) }\end{array}$ & $\begin{array}{l}r=0.64 \\
p=0.01\end{array}$ & $\begin{array}{l}\text { Chuine et al. } \\
\text { (2004) }\end{array}$ \\
\hline $\begin{array}{l}\text { Grape harvest } \\
(1523-1879)\end{array}$ & $\begin{array}{l}\text { Austria } \\
\text { (Vienna) }\end{array}$ & $\begin{array}{l}r=0.47 \\
p=0.01\end{array}$ & $\begin{array}{l}\text { Maurer et al. } \\
\text { (2009) }\end{array}$ \\
\hline $\begin{array}{l}\text { GHD, WGHD } \\
(1618-2010)\end{array}$ & $\begin{array}{l}\text { Western Hungary } \\
\text { (Kôszeg) }\end{array}$ & $\begin{array}{l}r=0.47 \\
p=0.01\end{array}$ & $\begin{array}{l}\text { Kiss et al. } \\
(2011)\end{array}$ \\
\hline $\begin{array}{l}\text { T-Index by } \\
\text { Glaser } \\
(1500-1760)\end{array}$ & Germany & $\begin{array}{l}r=0.46 \\
p=0.01\end{array}$ & $\begin{array}{l}\text { Dobrovolny et } \\
\text { al. (2010) }\end{array}$ \\
\hline $\begin{array}{l}\text { WGHD } \\
(1501-2008)\end{array}$ & $\begin{array}{l}\text { Czech Republic } \\
\text { (north western to } \\
\text { whole territory) }\end{array}$ & $\begin{array}{l}r=0.36 \\
p=0.01\end{array}$ & $\begin{array}{l}\text { Mozny et al. } \\
(2011)\end{array}$ \\
\hline
\end{tabular}

To further illuminate the characteristics of the new Basel WGHD reconstruction, the series is compared with fluctuations of Alpine glaciers. Glaciers in mountain areas are highly sensitive to climate changes and thus provide one of nature's clearest signals of warming or cooling and/or dry and wet climate periods including both conditions in the summer and winter half-year. Their fluctuations are primarily influenced by air temperature, while precipitation is the second most important climatic factor (Oerlemans, 2001). A comparison with glacier fluctuations may thus be well suited to further investigate the characteristics and validity of the WGHD series. At the same time, it may shed light on seasonal temperature trends being connected with glacier fluctuations. The Lower Grindelwald glacier in the Bernese Alps, which has a length of $>9 \mathrm{~km}$ and a surface area of $<18 \mathrm{~km}^{2}$ (Paul, 2003), is appropriate for such a comparison because it is close to the area of investigation and, considering the second half of the last millennium, is at the same time the most in detail researched "historic" glacier worldwide. The positions of its tongue up to the late nineteenth century were assessed from more than 360 paintings, drawings and photographs in combination with detailed written narratives from village chroniclers and visiting natural scientists (Zumbühl, 1976; Zumbühl and Messerli, 1983). The fluctuations of the glacier length after 1500 can be summarized as follows. There was a small advance prior to 1540 , followed by a substantial melting back. A long-term growth phase from about 1575 to 1602 resulted in an advance of about $1000 \mathrm{~m}$ (Pfister et al., 1994; Holzhauser and Zumbühl, 1999). From the mid seventeenth to the mid nineteenth century, the glacier snout did not melt back behind a local typical rock terrace situated about $1250 \mathrm{~m}$ below its present position. Over this period the ice advanced at seven times over distances of 400 to $600 \mathrm{~m}$ down into the valley floor, peaking around 1640, 1669, 1720, 1740, 1779, 1822 and 1856 (see illustrations in Holzhauser and Zumbühl, 2003). Since the end of the LIA, the tongue of the Lower Grindelwald glacier melted back by about $2 \mathrm{~km}$ to its present position up in the gorge, with smaller intermediate advances in the 1920s and 1970s (see graph in Holzhauser et 


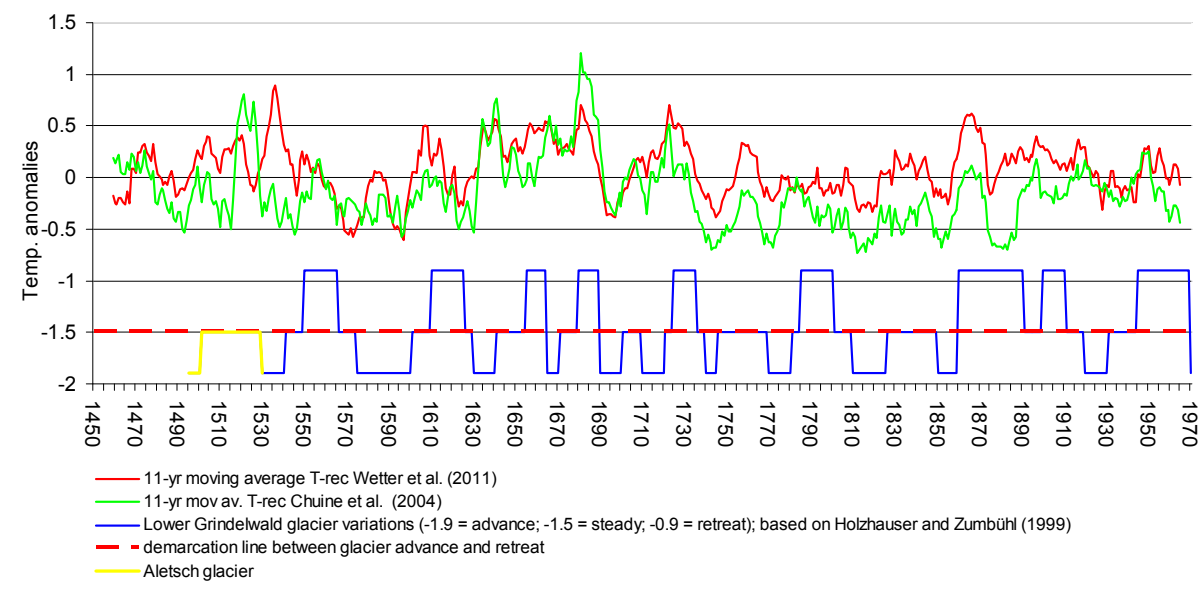

Fig. 11. Comparison between glacier fluctuations and reconstructed temperature anomalies by Basel WGHD- and Burgundy GHD series; $11-y r$ moving averages.

al., 2005). The variations of the glacier snout are summarized according to five-year periods distinguishing between advance, stationary state and melting back to allow visual comparison with the WGHD-based March to July temperature reconstruction (Fig. 11).

The long Burgundy GHD time series (Chuine et al., 2004) is included for comparison. In interpreting Fig. 11, one has to take into account the lag in the reaction of the glacier to climatic stimuli. There is disagreement between the GHD Burgundy and the WGHD Basel curve in the 1450s and again between 1518 and 1526, which would need to be disentangled with reference to narrative documentary sources. The long term decline of WGHD from 1540 to the lowest trough between 1570 and 1600 suggests a pronounced cooling of the March to July interval, which, between 1575 and 1602, was followed by a long term advance of the glacier to its foremost Little Ice Age position. This result agrees better with the model by Steiner et al. (2008) than the GHD series by Chuine et al. (2004) and Meier et al. (2007), perhaps because the decline of spring temperatures played a significant role in this advance. Likewise, the advance from 1690 to 1720 was primarily triggered by low spring temperatures and high spring precipitation, which also becomes evident through the pronounced delay of grain harvests preceding the advance in the 1850 s. On the other hand, low summer temperatures were the primary drivers of the advances 1770-1780 and 18101820 (Steiner et al., 2008), which are less clearly reflected in the WGHD curve. The end of the Little Ice Age around 1860 stands out by a long term shift towards earlier WGHD that has no equivalence in the GHD series. Despite differences in size and location, the variations of the Great Aletsch and the Lower Grindelwald glaciers show strong similarities over the last $3500 \mathrm{yr}$ (Holzhauser et al., 2005). From the relocation of water conduits in the glacier fore-field, Holzhauser (2009) concluded a minor advance of the Aletsch glacier culminating around 1505 . It seems to be connected to the cold dips of
March to July temperatures in the 1460s and again between 1480 and 1491 (Fig. 11). In general, the Basel WGHD series show better skills in representing variations of Alpine glaciers than both the Burgundy (Chuine et al., 2004) and the Swiss GHD series (Meier et al., 2007).

\section{Conclusions}

This paper presents a unique 517 yr long documentary databased reconstruction of spring-summer (MAMJJ) temperatures for northern Switzerland and south-western Germany from 1454 to 1970 derived from winter grain (mostly rye) harvest starting dates. The first part of the series (up to 1705) is mainly drawn from the books of daily expenditures kept by the Basel hospital in which wages paid to harvest workers are regularly laid down day by day. The second part of the series (from 1706 to 1970) is composed of three different kinds of evidence: (i) dates on which tithes (taxes) paid in grain was sold by auction (1706 to 1825), (ii) information of harvest work drawn from farmer's diaries (1824 to 1950), and (iii) phenological network observations (1950 to 1970).

The evidence for the period 1870 to 1949 , somewhat meagre and fragmentary, is only available in the form of published data without any reference to metadata, so that its quality can hardly be assessed. This shortcoming, related to the abandonment of keeping phenological, ice and snow observations alongside with instrumental measurements by nineteenth century meteorologists, is probably the Achilles heel of working with long series of institutional documentary data, as nineteenth and early twentieth century proxy evidence needed for the calibration/verification procedure, if it is available at all, often suffers from qualitative shortcomings. These shortcomings of recent evidence are reflected in the different level of correlations between the period 1774 $1869(r=0.69)$ and $1870-1949(r=0.54)$. In comparison 
with grape harvest dates, WGHD data have 3 advantages: (i) they also include information on March temperatures, (ii) they are also available for regions where grapes are not grown, and (iii) they have a higher skill in the temperature reconstruction of the pre-instrumental period concluding from the comparison of both WGHD and GHD series with known Alpine glacier fluctuations since the late fifteenth century. Probably, accounts on wages paid to agricultural workers by local authorities (municipalities, hospitals, etc.) may be readily available in other archives in Europe and elsewhere. Accordingly, more temperature reconstructions based on WGHD might become available in the future to improve and complete our picture of spring-summer temperatures in other regions of Europe.

\section{Supplementary material related to this article is available online at: http://www.clim-past.net/7/1307/2011/ cp-7-1307-2011-supplement.pdf.}

Acknowledgements. Acknowledgements are due to the Swiss National Science Foundation (Grant 100011-120157), the Oeschger Centre for Climatic Change Research (OCCR), H. A. VögelinBienz-Stiftung and the Institute of History at the University of Bern for funding support. Kathleen Pribyl, University of Brighton, and Alexandra Vlachos, University of Bern, are thanked for providing style corrections. We also thank Hans-Jürg Hauert from Grossaffoltern (Canton Bern) who made the diary of his ancestor available.

Edited by: J. Guiot

\section{References}

Allen, D. W. and Lueck, D.: The nature of the farm: contracts, risk, and organization in agriculture, VIII, MIT Press, Cambridge, Mass., 258 pp., 2002.

Auer, I., Böhm, R., Jurkovic, A., Lipa, W., Orlik, A., Potzmann, R., Schöner, W., Ungersböck, M., Matulla, C., Briffa, K., Jones, P. D., Efthymiadis, D., Brunetti, M., Nanni, T., Maugeri, M., Mercalli, L., Mestre, O., Moisselin, J.-M., Begert, M., MüllerWestermeier, G., Kveton, V., Bochnicek, O., Stastny, P., Lapin, M., Szalai, S., Szentimrey, T., Cegnar, T., Dolinar, M., GajicCapka, M., Zaninonvic, K., Majstorovic, Z., and Nieplova, E.: HISTALP - historical instrumental climatological surface time series of the Greater Alpine Region 1760-2003, Int. J. Climatol., 27, 17-46, 2007.

BFS - Bundesamt für Statistik: Die Bevölkerung der Schweiz 2009, Neuchâtel, 16 pp., 2010.

Blum, J.: The End of the Old Order in Rural Europe, Priceton, University Press, Princeton, New Jersey, 1978.

Bhm, R., Jones, P. D., Hiebl, J., Brunetti, M., Frank, D., and Maugeri, M.: The early instrumental warm-bias: A solution for long central European temperatures series 1760-2007, Climatic Change, 101, 41-67, 2010

Brázdil, R. and Kotyza, O.: History of Weather and Climate in the Czech Lands IV. Utilisation of Economic Sources for the Study of Climate Fluctuation in the Louny Region in the FifteenthSeventeenth Centuries, Masaryk University, Brno, 350 pp., 2000.

Brázdil, R., Pfister, C., Wanner, H., von Storch, H., and Luterbacher, J.: Historical Climatology in Europe - The State of the Art, Climatic Change, 70, 363-430, 2005.

Brázdil, R., Zahradníček, P., Dobrovolný, P., Kotyza, O., Valášek, H.: Historical and recent viticulture as a source of climatological knowledge in the Czech Republic, Geografie - Sborník České geografické společnosti, 113, 351-371, 2008.

Burkhardt, T. and Hense, A.: On the reconstruction of temperature records from proxy data in Mid Europe, Arch. Meteorol. Geophys. Bioclim., B35, 341-359, 1985.

Burri, M. and Zenhäusern, G.: Sprüngli und Inderschmitten, Blätter aus der Walliser Geschichte, 23, 34-46, 2009.

Chuine, I., Yiou, P., Viovy, N., Seguin, B., Daux, V., and Le Roy Ladurie, E.: Grape ripening as a past climate indicator, Nature, 432, 89-290, 2004.

Collins, E. J. T.: Harvest Technology and Labour Supply in Britain, 1790-1870, The Economic History Review, New Series, 22, 453-473, 1969.

Cook, E. R., Briffa, K. R., and Jones, P. D.: Spatial regression methods in dendroclimatology: A review and comparison of two techniques, Int. J. Climatol., 14, 379-402, 1994.

da Costa, N. N.: Von der Einsammlung des Getreides. in: Abhandlungen und Beobachtungen der Ökonomischen Gesellschaft Bern, 4, 76-87, 1763.

Diepenbrock, W., Fischbeck, G., Heyland, K.-U., and Knauer, N.: Spezieller Pflanzenbau, in: UTB, Verlag Eugen Ulmer, Stuttgart, 1999.

Diepenbrock, W., Elmer, F., and Léon, J.: Ackerbau, Pflanzenbau und Pflanzenzüchtung, in: UTB, Verlag Eugen Ulmer, Stuttgart, 2005.

Dobrovolný, P., Brázdil, R., Valášek, H., Kotyza, O., Macková, J., Halíčková, M.: A standard paleoclimatological approach to temperature reconstruction in historical climatology: an example from the Czech Republic, A.D. 1718-2007, Int. J. Climatol., 29, 1478-1492, 2009.

Dobrovolný, P., Moberg, A., Brázdil, R., Pfister, C., Glaser, R., Wilson, R., Engelen, A. van, Limanówka, D., Kiss, A., Halíčková, M., Macková, J., Riemann, D., Luterbacher, J., and Böhm, R.: Monthly, seasonal and annual temperature reconstructions for Central Europe derived from documentary evidence and instrumental records since AD 1500, Climatic Change, 101, 69-107, 2010.

Dubler, A. M.: Sense, in: Historisches Lexikon der Schweiz, http://www.hls-dhs-dss.ch/textes/d/D28683.php, last access: 29 November 2011, 2011.

DWD: Anleitung für die Beobachter des Deutschen Wetterdienstes (BAPH). Vorschriften und Betriebsunterlagen Nr. 17 (VuB 17), Dritte Auflage, Offenbach am Main, 189 pp., 1991.

Encyclopdia Britannica: Retrieved from http://www.britannica. com/EBchecked/topic/1514616/Central-European-climate, last access: 29 November 2011, 2011

Gauss, C. F.: Berechnung des Osterfestes, in: Monatliche Correspondenz zur Beförderung der Erd- und Himmelskunde, 2, edited by: von Zach, F. X., Gotha, 1800.

Glaser, R.: 1200 Jahre Wetter, Klima, Katastrophen, WBG, Darmstadt, 264 pp., 2008.

Glaser, R., Brázdil, R., Pfister, C., Dobrovolný, P, Barriendos, M., 
Bokwa, A., Camuffo, D., Kotyza, O., Limanówka, D., Rácz, L., abd Rodrigo, F. S.: Seasonal Temperature and Precipitation Fluctuations in Selected Parts of Europe During the Sixteenth Century, in: Climatic Variability in Sixteenth Century Europe and Its Social Dimension, edited by: Pfister, C., Brázdil, R., and Glaser, R., Climatic Change, Special Volume 43, 169-200, 1999.

Grotefend, H.: Taschenbuch der Zeitrechnung des deutschen Mittelalters und der Neuzeit, Dreizehnte Auflage, Hahnsche, Hannover, 224 pp., 2007

Holzhauser, H.: Die bewegte Vergangenheit des Grossen Aletschgetschers, in: Klimageschichte in den Alpen, Methoden - Probleme - Ergebnisse, edited by: Imboden, G. and Pfister, C., 41, Visp, 47-102, 2009.

Holzhauser, H. P. and Zumbühl, H. J.: Glacier Fluctuations in the Western Swiss and French Alps in the 16 Century, in: Climatic Variability in Sixteenth-Century Europe and Its Social Dimension, edited by: Pfister, C., Bràzdil, R. and Glaser, R., Kluwer, Dordrecht, 223-235, 1999.

Holzhauser, H. and Zumbühl, H. J.: Jungholozäne Schwankungen des Unteren Grindelwaldgletschers: fossile Böden und Bäume, historische Dokumente in: Geographica Bernensia, III, Bern, 23 pp., 2003.

Holzhauser, H., Magny, M., and Zumbühl, J.: Glacier and lakelevel variations in west-central Europe over the last 3500 years, Holocene, 15, 789-801, 2005.

Hughes, C.: Switzerland, in: Nations of modern world, III, London, 303 pp., 1975

Jankovic, V.: Reading the skies, A cultural history of English Weather, 1650-1820, Manchester University Press, Manchester, 272 pp., 2000.

Kiss, A., Wilson, R., and Bariska, I.: An experimental 392year documentary-based multi-proxy (vine and grain) reconstruction of MayJuly temperatures for Kszeg, West-Hungary, Int. J. Biometeorol., 5504, 595-611, 2011.

Lauer, W. and Frankenberg, P.: Zur Rekonstruktion des Klimas im Bereich der Rheinpfalz seit Mitte des 16. Jahrhundert mit Hilfe von Zeitreihen der Weinquantität und Weinqualität, Gustav Fischer, Stuttgart, New York, 54 pp., 1986.

Le Roy Ladurie, E.: Histoire du climat depuis l'an mil, in: nouvelle bibliothèque scientifique, Flammarion, Paris, 376 pp., 1967.

Le Roy Ladurie, E. and Baulant, M.: Grape harvests from the fifteenth through the nineteenth centuries, J. Interdisciplin. Hist., 10, 839-849, 1980.

Leijonhufvud, L., Wilson, R., and Moberg, A.: Documentary data as proxy variables for Stockholm late winter to early spring temperatures in the 18th and 19th centuries, Holocene, 18, 333-343, 2008

Leijonhufvud, L., Wilson, R., Moberg, A., Söderberg, J., Retsö, D., and Söderlind, U.: Five centuries of Stockholm winter/spring temperatures reconstructed from documentary evidence and instrumental observations, Climatic Change, 101, 109-141, 2010.

Mariani, L., Parisi, S., Failla, O., Cola, G., Zoia, G., and Bonardi, L.: Tirano (1624-1930): A long time series of harvest dates for grapevine, Ital. J. Agrometeorol., 14, 7-16, 2009.

Maurer, C., Koch, E., Hammerl, C., Hammerl, T., and Pokorny, E.: BACCHUS temperature reconstruction for the period 16th to 18th centuries from Viennese and Klosterneuburg grape harvest dates, J. Geophys. Res., 114, D22106, doi:10.1029/2009JD011730, 2009.
Meier, N., Rutishauser, T., Pfister, C., Wanner, H., and Luterbacher, J.: Grape harvest dates as a proxy for Swiss April to August temperature reconstructions back to AD1480, Geophys. Res. Lett., 34, L20705, doi:10.1029/2007GL031381, 2007.

Menzel, A.: A 500 year pheno-climatological view on the 2003 heatwave in Europe assessed by grape harvest dates, Meteorol. Z., 14, 75-77, 2005.

Miedaner, T.: Roggen, Vom Unkraut zur Volksnahrung, DLG, Frankfurt am Main, 151 pp., 1997.

Mozny, M., Brázdil, R., Dobrovolny, P., and Trnka, M.: Cereal harvest dates in the Czech Republic between 1501-2008 as a proxy for March-June temperature reconstruction, Climatic Change, in press, doi:10.1007/s10584-011-0075-z, 2011.

Nordli, P. Ø.: Reconstruction of Nineteenth Century Summer Temperatures in Norway by Proxy Data from Farmers'Diaries, Climatic Change, 48, 201-218, 2001.

Nordli, P. Ø.: Norwegian farmers' diaries used for quality control and calibration of early instrumental observations, and for temperature reconstructions, The Norwegian Meteorological Institute, Climatology Department, Oslo, 2007.

Nordli, P.Ø., Lie, Ø., Nesje, A., and Dahl, S. O.: Spring-summer temperature reconstruction in western Norway 1734-2003: A data-synthesis approach, Int. J. Climatol., 23, 1821-1841, 2003.

Oerlemans, J.: Glaciers and Climate Change, Swets \& Zeitlinger BV, Lisse, 148 pp., 2001.

Paul, F.: The new Swiss glacier inventory 2000, Application of remote sensing and GIS, PhD Thesis, Department of Geography, University of Zürich, 2003.

Persson, K. G.: Grain Markets in Europe, 1500-1990, Integration and deregulation, Cambridge University Press, Cambridge, 1999.

Pfister, C.: Getreide-Erntebeginn und Frühsommertemperaturen im schweizerischen Mittelland seit dem frühen 17. Jahrhundert, Geograph. Helvet., 34, 23-25, 1979.

Pfister, C.: Klimageschichte der Schweiz 1525-1860, Das Klima der Schweiz von 1525-1860 und seine Bedeutung in der Geschichte von Bevölkerung und Landwirtschaft, in: Academica Helvetica 6, Bd. 1, Bern, Stuttgart, 184 pp., 1984.

Pfister, C.: Variations in the spring-summer climate of Central Europe from the High Middle Ages to 1850 in: Long and Short Term Variability of Climate, Wanner H, Siegenthaler, U. (ed.), Springer, Berlin, Heidelberg, New York, London, Paris, Tokyo, 57-82, 1988

Pfister, C.: Monthly temperature and precipitation patterns in Central Europe from 1525 to the present, A methodology for quantifying man-made evidence on weather and climate, in: Climate since A.D. 1500, edited by: Bradley, R. S. and Jones, P. D., Routledge, London, 118-142, 1992.

Pfister, C.: Wetternachhersage, 500 Jahre Klimavariationen und Naturkatastrophen 1496-1995, Haupt, Bern, 304 pp., 1999.

Pfister, C.: The vulnerability of past societies to climatic variation: a new focus for Historical Climatology in the 21st Century, Climatic Change, submitted, 2010.

Pfister, C., Holzhauser, H. P., and Zumbühl, H. J.: Neue Ergebnisse zur Vorstossdynamik des Grindelwaldgletschers vom 14. bis zum 16. Jahrhundert, in: Mitteilungen der Naturforschenden Gesellschaft Bern, N. F., 51, 55-79, 1994.

Pfister, C., Luterbacher, J., Wanner, H., Wheeler, D., Brázdil, R., Ge, Q., Hao, Z., Moberg, A., Grab, S., and Rosario Del, P. M.: 
Documentary evidence as Climate Proxies, Proxy-specific White Paper produced from the PAGES/CLIVAR workshop, Trieste, 2009.

Pribyl, K., Cornes, C. R., and Pfister, C.: Reconstructing medieval April-July mean temperatures in East Anglia, 1256-1431, Climatic Change, in press, 2011.

Rothen, M.: Die phänologischen Beobachtungen aus dem Schaffhauser Amtsblatt von 1876-1950, BA Thesis, Institute of History (Section WSU), University of Bern, Bern, 55 pp., 2009.

Rutishauser, T., Luterbacher, J., Jeanneret, F., Pfister, C., and Wanner, H.: A phenology-based reconstruction of interannual changes in past spring seasons, J. Geophys. Res., 112, G04016, doi:10.1029/2006JG000382,, 2007.

Schnelle, F., Pflanzen-Phänologie, in: Probleme der Bioklimatologie Band 3, edited by: De Rudder, B., Ruttner, F., and Steinhauser, F., Akademische Verlagsgesellschaft Geest und Portig, Leipzig, 299 pp., 1955.

Schüepp, M., Bouët, M., Bider, M., and Urfer, C.: Klimatologie der Schweiz Band II. Regionale Klimabeschreibungen, 1. Teil Gesamtübersicht, Westschweiz, Wallis, Jura und Juranordfuss sowie Mittelland, Beiheft zu den Annalen der Schweizerischen Meteorologischen Zentralanstalt, Schweizerische Meteorologische Zentralanstalt, Zürich, 123 pp., 1978.

Souriau, A. and Yiou, P.: Grape harvest dates for checking NAO paleoreconstructions, Geophys. Res. Lett., 28, 3895-3898, 2001.

Steiner, D., Zumbühl, H. J., and Bauder, A.: Two Alpine Glaciers over the Past Two Centuries: A Scientific View Based on Pictorial Sources, in: Darkening Peaks: Glacier Retreat, Science, and Society, edited by: Orlove, B., Wiegandt, E., and Luckman, B. H., University of California Press, Berkeley, Los Angeles, London, 83-99, 2008.
Tarand, A. and Kuiv, P.: The beginning of the rye harvest - a proxy indicator of summer climate in the Baltic Area, in: Climatic trends and anomalies in Europe 1675-1715, edited by: Frenzel, P. and Glaeser, B. C., Gustav Fischer, Stuttgart, Jena, New York, 61-72, 1994.

Tarand, A. and Nordli, Ø.: The Tallinn temperature series reconstructed back half a millennium by use of proxy data, Climatic Change, 48, 189-199, 2001.

Titow, J. Z.: Medieval England and the Open-Field System, Past Present, 32, 86-100, 1965.

Tschiffeli, J. R.: Auszug aus den Abhandlungen des Herrn De L'Isle und des Herrn Seigneux de Correvon (...) über die Frage: Ist es nützlicher, sich bey der getreidernte der Sense oder der Sichel zu bedienen?, in: Abhandlungen und Beobachtungen der Ökonomischen Gesellschaft Bern, 3, 199-219, 1762.

von Tscharner-Aue, M.: Die Wirtschaftsführung des Basler Spitals bis zum Jahre 1500, Ein Beitrag zur Geschichte der Löhne und Preise, in: Quellen und Forschungen zur Basler Geschichte, Staatsarchiv des Kantons Basel-Stadt, Basel, 409 pp., 1983.

Wegmann, M. A.: Naturwahrnehmung im Mittelalter im Spiegel der lateinischen Historiographie des 12. und 13. Jahrhunderts, in: Lateinische Sprache und Literatur des Mittelalters, 40, Peter Lang, Berlin, 240 pp., 2005.

Wikipedia: http://en.wikipedia.org/wiki/Rye, last access: 29 November 2011, 2011.

Zumbühl, H. J.: Die Schwankungen des Grindelwaldgletschers in den historischen Bild- und Schriftquellen des 12. bis 19. Jahrhunderts, Sonderdruck, Basel, 12-50, 1976.

Zumbühl, H. J. and Messerli, B.: Gletschergeschichte im Spiegel der Kunst: Sonderaustellung des Schweizerischen Alpinen Museums Bern und des Gletschergarten-Museums Luzern, Bern, 60 pp., 1983. 